\title{
Hammarskjöld and Human Rights: the Deflation of the UN Human Rights Programme 1953.1961
}

\author{
Jeff King and A.J. Hobbins McGi11 University
}

Dag Hammarskjöld became Secretary-General of the United Nations on 31 March 1953 following the resignation of Trygve Lie. He was ultimately elected as a compromise candidate about whom little was known. ${ }^{1}$ An economist, he had been Swedish UnderSecretary for Finance (1935-1947), before moving to the Foreign Affairs Ministry. His nominators felt he would prove a restrained and sound administrator, preferable to an outspoken politicalleader. ${ }^{2}$ The Americans, who bluntly asked "Who is this guy?", 3 set out to gather a dossier of information on him. It revealed " ... a Swedish civil service aristocrat, gifted administratively, UNbtrusive rather than flamboyant, a brilliant technician, an executant rather than political leader, and, some feared, a compromiser rather than fighter". ${ }^{4}$ Carl Schürman, the Netherlands representative at the UN, mentioned that it was

... the wish of the Big Powers to see -after Trygve Lie who had taken a strong position on several questions -at the head of the Secretariat someone who would concentrate mainly on the administrative problems and who would abstain from public statements on the political conduct of the Organization. Such a careful and colourless official they thought to have found in Dag Hammarskjöld. ${ }^{5}$

\footnotetext{
* Jeff King BCL/LLB (McGill, 2(03) is currently practising in New York City and A.J. Hobbins Associate Director of Libraries at McGill University. This article is based on a research essay prepared by King underHobbins' supervision. The authors would like to thank Johanne Pelletier and Gordie Burr of the McGill University Archives for providing access to the Humphrey papers. Professors Mary Ann Glendon (Harvard) and Stephen Toope (McGill) were kind enough to offer comments on various drafts.
}

1 Lester Pearson (Canada), nominated by France and Great Britain, had gained the most votes, but was vetoed by the Soviet Union because of his stance on the Korean War. Stanislaw Skreszewski (Poland), supported by the Soviet Union, and the General Romulo (Philippines), nominated by the US, did not enjoy wide support. France and Great Britain then proposed that Hammarskjöld be considered. See Brian Urquhart, Hammarskjöld (New York: Alfred Knopf, 1972), at p. 11.

${ }_{2}$ Joseph Lash, Dag Hammarskjöld: Custodian of the Brushfire Peace (New York: Doubleday, 1961), at p. 8 .

3 Ibid.

4 Ibid.

${ }_{5}$ Urquhart, supra note 1 , at p. 15. 
Within the Swedish government Hammarskjöld was regarded as an economic expert and technician rather than a politician. ${ }^{6}$ It was concluded that "Hammarskjöld was elected because he was assumed to be without ambition or assertiveness. It was believed that he was adept at not giving offence". ${ }^{7}$

Hammarskjöld was an attractive choice to the Western powers. ${ }^{8}$ He had written openly against Marxism as an economic and political ideology, ${ }^{9}$ and the Soviets had heated exchanges with him when he served as Swedish Deputy Minister of Foreign Affairs. ${ }^{10}$ Both the UK and the US had regarded him as having very pro-Western views. ${ }^{11}$ It thus came as a surprise to some that he was elected Secretary-General with the support of the Soviet Union. The presumed reason for this Soviet acquiescence was the intern al turmoil created by the death of Joseph Stalin on 5 March 1953. Stalin had eliminated or marginalized any clear successor and, in the power struggle that followed, it was difficult for Soviet Representative Andrei Vishinsky to get any clear instructions. Hammarskjöld's name was proposed immediately following Vishinsky's return from Moscow with directions to push for a new "peace offensive" and his "happiness" with the nomination was promptly declared. ${ }^{12}$

The Great Powers were only partially right in their estimates of Hammarskjöld. $\mathrm{He}$ would prove himse1f more than willing to immerse himself in political affairs, using the office of Secretary-General on many high-level diplomatic initiatives aimed at mediation and conflict resolution. However, he would also use his administrative skills to reorganize the UN Secretariat, cutting back in a number of areas. Secretariat support for the UN human rights programme was affected more than any other sector. This artic1e examines Hammarskjöld's attitude towards human rights in the broader context of his other activities as Secretary-General. It concludes that his policies of de-emphasizing the UN human rights programme were not justified by the reasons generally attributed to him.

${ }_{6}$ Mark Zacher, Dag Hammarskjöld's United Nations (New York: Columbia University Press, 1970), at p. 10 .

${ }_{7}$ Abba Eban, The New Diplomacy (New York: Random House, 1983), at p. 271.

8 Zacher, supra note 6, at p. 10: "Dag Hammarskjöld was culturally and politically a Westerner and a European. His own adherence to the values of the West had a deep foundation in his Christian religion and his study ofWestern history and philosophy."

9 Dag Hammarskjöld, "To Choose Europe" (Copenhagen: United Nations, Information Center for Denmark, Iceland, Norway and Sweden, 1952, original in Swedish).

${ }_{10}$ See Zacher, supra note 6, at pp. 18-19 for a brief treatment of his rejection of Marxism, and Lash, supra note 2, at p. 9 for a discus sion of the incident involving the exchange of curt correspondence regarding two Swedish planes being shot down over the Baltic by Soviet forces.

11 James Barros, Trigve Lie and the Cold War: The UN Secretary-GeneralPursues Peace 19461953 (Dekalb: Northern Illinois University Press, 1989), at p. 340.

${ }_{12}$ Urquhart,supranote 1, atp. 12. 


\section{Hammarskjöld's Vision of the Role of the United Nations}

A brief outline of Hammarskjöld's vision of the role of the UN in general and the Secretary-General in particular may provide a helpful frame of reference when considering his actions towards the human rights programme. ${ }^{13} \mathrm{He}$ emphasized impartiality, dedication to the principles embodied in the UN Charter, respect for the equality and sovereignty of smaller States, respect tor internationallaw, ${ }^{14}$ and the use of quiet and preventive diplomacy as a supplement or alternative to open-covenant diplomacy. He also favoured a highly active role for the UN Secretariat in the field of diplomacy, which continued but enhanced the tradition of his predecessor, and which has some justification in the Charter of the United Nations. ${ }^{15}$ In 1955, Hammarskjöld outlined what he viewed as "The Role of the Organization in Diplomacy", and stated that it was his hope"... that solid progress can be made in the coming years in developing new forms of contact, new methods of deliberation and new techniques of reconciliation". ${ }^{16}$ By 1957, he articulated much the same vision under the broader title "Role of the United Nations". ${ }^{17}$ By this point it appeared that his view of the purpose of the UN was based more on his own conception of the use of his office in particular than on the various purposes set forth in Article 1 of the Charter. His justification was stated plainly: "The greatest need today is to blunt the edges of conflict among the nations, not to sharpen them. If properly used, the United Nations can serve a diplomacy of reconciliation better than other instruments available to the Member States." 18

\footnotetext{
13 The best methodological analysis of Hammarskold's work is Zacher, supra note 6. See also Andrew Cordier, "Motivations and Methods of Dag Hammerskjold", in Andrew Cordier and Kenneth Maxwell, Paths to World Order (New York: Columbia University Press, 1967). Urquhart, supra note I (for a very well-written chronological examination interlaced with commentary upon methods); Mark Zacher, "Hammarskjöld's Conception of the United Nations Role in World Polities", also in Cordier and Maxwell, at p. 111. For period pieces see Joseph P. Lash, "Dag Hammarskjöld's Conception of His Office" (1962) XVI International Organizationp. 542; Elmore Jackson, "The Developing Role of the Secretary-General" (1957) XI International Organization p. 431. Each of these is quite sympathetic to Hammarskjöld. More critical views are presented below.
}

${ }_{14}$ Oscar Schacter, "Dag Hammarskjöld and the Relation of Law to Politics" (1962) LVI American Joumal of International Law p. I.

${ }_{15}$ See Article 1 (1) and Article 2, the latter of which is nearly exclusively concerned with international peace and security. Article 99 of the Charter: "The Secretary-General may bring to the attention of the Security Council any matter that in his opinion may threaten international peace and security."

${ }_{16}$ Annual Report of the Secretary-General on the Work of the Organization, UN GAOR, 10th Sess., Supp. No. I, UN Doc. A/2911 (1955), at p. xii.

17 Introduction to the Annual Report of the Secretary-General on the Work of the Organization, UN GAOR, 12th Sess., Supp. No. IA, UN Doc. A/3594/Add.1 (1957) at p. 3.

${ }_{18}$ Ibid. Hammarskjöld also defended the policy of "one nation one vote" against its critics. 
In the art of diplomacy, Hammarskjöld was noted for at least three distinct approaches: vacuum theory, quiet diplomacy, and preventive diplomacy. The "vacuum theory", the most original of these, was based on the idea that when a conflict arose in a region not yet fully embroiled in Cold War polities, he could fill that vacuum through diplomatic contact. ${ }^{19}$ This would " ... localize conflict and keep the great powers apart". ${ }^{20}$ However a survey of the practice reveals rather that the Secretary-General did not always in fact fill vacuums, but sometimes acted as broker for the Great Powers.

On social matters Hammarskjöld seemed to have favoured a more conservative approach, and increasingly neglected this side of his role at the $\mathrm{UN} .{ }^{21}$ On the question of self-determination, not to mention human rights, he supported only gradual change in the status quo. In 1956 he wrote "[b]oth unrealistic impatience in the movement toward self-determination and wasteful resistance to it would contradict [the] philosophy of the Charter by leading to conflicts which might threaten peace". ${ }^{22}$ Even as early as January 1954, John Peters Humphrey, ${ }^{23}$ while his respect for Hammarskjöld 's intelligence and integrity was still quite strong, wrote in his diary:

He continues to be an enigma for me. That he is keenly intelligent there can be no doubt. I also find myself in agreement with him on specific issues. But I wonder about the direction in which he is going. I sometimes think that his purpose is to reduce the nonpolitical activities of the organization to a minimum. ${ }^{24}$

Humphrey would shortly discover that there was some substance to his reservations.

1" Arthur W. Rovine, The First Fifty Years: The Secretary-General in World Politics 1920-1970 (Leyden: AW Sijthoff, 1970), at p. 332. The author cites Gaza, Lebanon and Jordan, Laos and the Congo as successes of this policy.

${ }_{20}$ Ibid.

21 See Bertram Ramcharan, Humanitarian Good Offices in International Law (The Hague: Martinus Nihjhoff, 1983), at pp. 22-27; Thomas George Weiss, International Bureaucracy (Lexington: DC Heath, 1975) at pp. 92-93, where it is stated: "The 1955 and 1956 reports evidenced a greater uncertainty of Hammarskjöld 's part with respect to the ultimate merits of welfare cooperation. There was no longer the voiced enthusiasm or optimism that marked his earlier functional pronouncements. A more traditional concern with the UN's diplomatic role emerged."

22 Introduction to the Annual Report of the Secretary-General on the Work of the Organization, UN GAOR, 11 th Sess., Supp. No. IA, UN Doe. A/3137 /Add. 1 (1956) at p. 2.

${ }_{23}$ John Peters Humphrey (1905-1995), Canadian lawyer and academic, was the first Director of the UN Division of Human Rights (1946-1966). Many of the primary materials used for th is paper are to be found in the Humphrey Collection, McGill University Archives, MG 4127. Nations Division of Human Rights: Volume 3, 1952-1957(Montreal: McGill University Libraries, 1998), at p. 55 (diary en try, 29 January 1954). 


\section{Hammarskjöld's Political Activities as Secretary-General of the United Nations, 1953-1961}

Hammarskjöld's political activities have been chronicled in some detail and are only briefly listed here. They began immediately, though cautiously, after his appointment. In 1953, he grappled with the remains of the conflict and emerging armistice in Korea. In June 1954, his involvement in the Guatemalan affair led to his first unsuccessful clash with a major power, the US. ${ }^{25}$ The government of Guatemala was subject of a CIA-assisted coup, and appealed to the Security Council for help. The President of the Council, Henry Cabot Lodge Jr. (US), declared that Article 52 of the Charter required that consideration of the matter go before the Organization of American States rather than the UN Hammarskjöld privately objected to this tenuous interpretation of Art. 52, but was advised by the British not to present his more persuasive interpretation to the Security Council tor fear of alienating the US. ${ }^{26}$ He later issued the interpretation by way of a memorandum, and was heavily reproached by the US administration for it. ${ }^{27}$

Hammarskjöld's next adventure involved the unprecedented use of his office, at the request of the US, ${ }^{28}$ to negotiate the release of numerous American Air Force personne1 who came down in Chinese territory while allegedly serving in the United Nations Unified Command in Korea.1t was later confirmed, as China alleged at the time, that at least two of the prisoners had worked for the CIA and were not part of the UN force. ${ }^{29}$

${ }_{25}$ Urquhart, supra note 1, at pp. 88-94.

${ }_{26}$ Ibid at p. 92. "Dixon [United Kingdom] implored him not to make [the statement at the Security Council on the grounds that it would force him to change his speech and vote against the United States instead of abstaining, and also that it would almost certainly cause the United States to walk out of the Council".

${ }_{27}$ It did not help Hammarskjöld that ten of the eleven Security Council members agreed with the US position, the Soviet veto nonetheless blocking a formal declaration. The leftist Arbenz government succumbed to the coup on 27 June 1954, rendering any subsequent resistance at the UN level largely moot. Despite heated exchanges with Lodge, and US State Department allegations of potential bias, Urquhart reports that by August of that year Hammarskjöld " ... enjoyed himself fully in the Lodge family circle, and after this his official disagreements with Lodge were offset by personal friendship and mutual understanding". Ibid. at p. 94.

28 Although the State Department initially wrote to Hammarskjöld directly, it later sponsored a General Assembly resolution (A/L 182,7 December 1954) calling for the release of all UN personnel detained in violation of the Korean armistice agreement. The negotiations and eventual release, however, dealt only with the detained Americans. The Chinese Government was later incensed that Hammarskjöld's report to the General Assembly implied that discussions would be continued in order to secure the release of "all the other captured UN personnel", when no discussion of this personnel took pi ace during the negotiations. Ibid. at p. 129.

${ }_{29}$ As discussed in Urquhart, ibid. at pp. 107-108. 
The matter was complicated by the fact that the People's Republic of China was not then a member of the UN, which still recognized the regime of Chiang Kaishek. ${ }^{30}$ After some six months of negotiations, Chou En-Lai of China agreed to release the American prisoners largely as a gesture of good faith towards the personality and not the office of the Secretary-General. Those warm relations froze when Hammarskjöld's report to the General Assembly ${ }^{31}$ apparently characterized the Chinese actions as compliance with the General Assembly resolution, rather than as independent initiative, and that the prisoners were referred to as UN personnel when the Chinese position was that they were spies. The matter ended with forceful Chinese accusations of lack of impartiality. Nonetheless, by 1955, the Secretary-General reported to the General Assembly "[n]ow, in the situation that seems to be developing, this role of the United Nations should acquire a new diplomatic and political significance". ${ }^{32}$

Hammarskjöld's subsequent diplomatic interventions grew in number and prestige. He intervened in the Middle East, in April and May of 1956. The United Nations formed its first international peacekeeping force (United Nations Emergency Force UNEF) as a response to the Suez Crisis between Egypt, France, Britain and Israel in August 1956. Simultaneously Hammarskjöld was faced with the Hungarian crisis, in which Hungary appealed to the UN to assist it in responding to the Soviet decision to maintain a military presence in that country. In May 1958, he spearheaded the United Nations Observation Group in Lebanon (UNGIL). The Group was sent to determine whether foreign assistance, primarily from Egypt, was being used to create political and military instability in the country. In the same year, his office was called upon to exercise a conciliatory role between Tunisia and France. Tunisia had been bombed by French forces for alleged complicity in attacks against French Algeria, and responded by surrounding and isolating French military outposts in Tunisia. Also in 1958 he was called upon by Thailand and Cambodia to send a representative to quell rising tensions over a border dispute. The request was granted, and resulted in an encouraging success. Conversely, his efforts to deal with the rising Cold War tensions in Laos, which began in January 1959, were largely in vain. ${ }^{33}$ These tensions reached their apex in the Congo crisis, July and August of 1960. While the Secretary-General's various attempts at diplomacy and occasional responses to the politically divisive resolutions of the General Assembly met with varied success, the operation in the Congo is the one that

${ }_{30}$ Hammarskjöld had in fact advocated the inclusion of Communist China in the UN in a speech on 18 March 1954 at the Pilgrim's dinner in London. Hobbins, supra note 24, at p. 59.

${ }_{31}$ Complaint of Detention and Imprisonment of UN Military Personnel in Violation of the Korean Armistice Agreement: Report of the Secretary Genera/. General Assembly Plenary DocumentA/2954, September 9, 1955.

${ }_{32}$ Annual Report of the Secretary-General on the Work of the Organization, UN GAOR, 10th Sess., Supp. No. 1, UN Doe. A/2911(1955) at xi-xii.

${ }_{33}$ Urquhart, supra note 1, at 367. 
generated the greatest controversy. ${ }^{34}$ In addition to these diplomatic activities, he undertook advancements in disarmament, ${ }^{35}$ and in economic development of underdeveloped countries. ${ }^{36}$

\section{The Social Department}

The Social Department of the UN Secretariat had enjoyed a high-profile role under Trygve Lie. Although Lie himself was not much involved in social affairs, he delegated much authority to the active and enthusiastic Assistant Secretary-General for Social Affairs, Henri Laugier. In turn Laugier gave both encouragement and leeway to his protégé John Humphrey, who directed the Division of Human Rights (DHR) from 1946-1966. The DHR had been involved in the development of the Universal Declaration of Human Rights, considered one of the UN's greatest achievements, and the initial work on the planned Convention. Ill-health obliged Laugier to resign in 1951 and he was replaced by French diplomat Guillaume Georges-Picot. ${ }^{37}$ Lie would shortly be succeeded by Hammarskjöld, whose man date included the streamlining of the Secretariat. For the future of the Social Department much would depend on the relationship between Hammarskjöld and Georges-Picot and how well the latter would be able to put the Department's case in the coming retrenchment.

\section{The Reorganization of the Secretariat}

Morale in the Secretariat had been low before Hammarskjöld's appointment, largely because of Trygve Lie's acceptance of the Un-American activities investigation of the UN staff and subsequent dismissals. Some officials noted that morale increased immediately upon Hammarskjöld's arrival. ${ }^{38}$ During the first weeks of his tenure he

${ }_{34}$ See Lash, supra note 6, at p. 223; Urquhart ibid. at pp. 389-457; Ralph J. Bunche, "The United Nations Operation in the Congo", in Andrew Cordier and Wilder Foote (eds.) The Quest for Peace: The Dag Hammarskjöld Memorial Lectures (New York: Columbia University Press, 1965) p. 119 (for a sympathetic, firsthand account); Ernest W. Lefever, Crisis in the Congo: A UN Force in Action (Washington, D.C.: Brookings, 1964).

${ }_{35}$ See Alva Myrdal, "Disarmament in the United Nations", in Cordier and Foote, ibid. at p. 149.

36 See Philippe de Seynes, "An Informal Retrospection on Dag Hammarskjöld 's Commitment to Economic and Social Development", in Robert S. Jordan, Dag Hammarskjöld Revisited (Durham: Carolina Academic Press, 1983) p. 65.

${ }_{37}$ Georges-Picot was a career diplomat who held a number of ambassadorial posts before and after his brief stint as Assistant Secretary-General. He was more interested in the executive functions of the UN than the social programmes.

${ }_{38}$ Hobbins, supra note 24, at p. 51. On 1 May 1953, Humphrey writes "Reports from Headquarters indicate that morale has greatly improved since the election of the new Secretary -General. That and the apparent improvement in the international situation are other reasons why I am not interested in becoming Registrar of the [International] Court [of Justice]". Humphrey's name was discussed as a potential candidate for election to the position of Registrar. He wrote to Judge John Read and declared that he was not interested in the position (see diary entry for 5 May 1953). 
reportedly visited, with his Executive Assistant Andrew Cordier, singly or in groups, all of the 3,500 members of the staff. ${ }^{39}$ Shortly thereafter he embarked upon a review of the Secretariat prior to reorganization. ${ }^{40}$

Hammarskjöld began the review process by appointing a six-person Survey Group of senior members of the Secretariat early in 1954. The names of the members of the Group and its final report were never published. However, Ralph Bunche (the topranking Director in the Department of Trusteeship and Information from Non-Self Governing Territories), Julia Henderson (Director of the Division of Social Welfare), and Alfred Katzin (Director of the Bureau of Personnel) have been identified as members. $^{41}$ It also seems probable that Martin Hill (Deputy Executive Assistant to the Secretary-General) and Bruce Turner (Executive Officer in Office of the Secretary-General and later, in 1955, Controller), as well as Cordier would have participated in the group discussions. Katzin and Bunche played key roles in reporting on the work of the Group at the Secretary-General's private meetings. ${ }^{42}$ In July 1954, Hammarskjöld described for ECOSOC the philosophy of the reorganization as a reconsideration of the efforts and direction of the work of the UN, and the role of the Secretariat in this function. ${ }^{43} \mathrm{He}$ noted that throughout the process, the Survey Group had around 75 meetings with officials concerned with various activities of the UN, and drew up policy lines on the basis of those hearings. The aims of the reorganization were greater organizational efficiency, improved staffing arrangements and budgetary savings. ${ }^{44}$

39 Andrew Cordier, "Motivations and Methods of Dag Hammerskjold", in Cordier and Maxwell, Supre note 13,1 at p. 15 .

${ }_{40}$ See Annual Report of the Secretary-General on the Work of the Organization, UN GAOR, 9th Sess., Supp. No. 1, UN Doe. A/2663 (1954), at pp. xiv-xv for a brief discussion of this review.

${ }_{41}$ John P. Humphrey, United Nations and Human Rights: A Great Adventure (Dobbs Ferry: Transnational Publishers, 1984), at p. 183 (Katzin, Henderson), p. 185 (Bunche).

${ }_{42}$ Minutes to the Secretary-General's Private Meeting No.43 (7 May 1954), McGill University Archives, MG 4127, Cont. 23, File 476, for an example of Katzin's prominent role in personnel policy; Minutes to the Secretary-General's Private Meeting No. 68, (20 May 1955) and No. 78 (16 September 1955) for examples of Bunche's reporting function on the work of the Survey Group. McGill University Archives, MG 4127, Cont. 23, File 477.

${ }_{43}$ Statement to ECOSOC Introducing Item 29, Geneva 5 July 1954, reprinted in Andrew W. Cordier and Wilder Foote, Public Papers of the Secretary-Genera4 Vol. 2 1953-56 (New York: Columbia University Press, 1969), at p. 315.

${ }_{44}$ Report of the Secretary-General on the Organization of the Secretariat, UN GAOR, 9th Session, Annex, Agenda Item 53, UN Doc. A/2731 (1954) at para. 3. 
Georges-Picot was unfortunately absent from the Secretariat for much of 1954, leaving Humphrey as Acting ASG of the Department. Humphrey met with Hammarskjöld concerning the reorganization several times. He reported:

On Tuesday he called me to his office "to acquaint me with his thinking" about the reorganization of the Social Department. This thinking is not supposed to crystallize until Georges-Picot returns; but it is obvious that the S.G. had already established broad lines of his reorganization in his mind even before he began his review.

The activities which will suffer most in the Social Department are population and human rights. The former all but disappears becoming a unit in Julia Henderson's service -the only one in the Department, incidentally, which shows any expansion. The Human Rights Division becomes an Office. When I later asked Katzin the significance of this he said it was to underline the fact th at responsibility for "establishing policy would be at a higher" level. The number of sections are reduced from 5 to 3 with a corresponding reduction in P5 officers. The deputy director will also be a section chief so that the posts of three of the present section chiefs will be eliminated. The over-all reductions in the manning table would be $18-10$ professional officers and 8 secretaries. Of course, says the S.G., this is only a target -the actual operation would take from two to three years to complete.

I warned him that as far as human rights at least are concerned he is making a great mistake. The work load should in fact increase as soon as the Commission finishes with the draft covenant. The S.G. therefore will mere1y expose himself to attack without being at all sure that he can achieve his objective. But I mightjust as weIl have saved my breath. He is very sure of himself and his mind is made up.

Two things that he said to me are worth putting down for the record. He would like to throw the Human Rights Covenants out the window. I checked him up on this and suggested that a better policy would be to put them on ice until there is an improvement in the political climate. Later when boasting about what he called the successful elimination of the Department of Financial and Administrative Services, he said that he found that he could do himse1f everything that the A.S.G. had done in the past. This kind of activity, he said, was more useful than seeing delegations "which was a waste of time". That remark, I think, gives the true measure of the man. In spite of his brilliant mind and his possible (but yet unproved) administrative ability he lacks the qualities of statesmanship. ${ }^{45}$

It is clear that even at this juncture the decision had already been made to merge the Economic and the Social Department into one unit. When Georges-Picot returned he told Humphrey of his intention to tell Hammarskjöld that he would not stay on unless changes were made to the Reorganization Plan. ${ }^{46}$ Predictably his discussions with the Secretary-General did not go well. In March 1954 Humphrey noted:

${ }_{45}$ Hobbins, supra note 24, at pp. 56-57 (diary entry, 13 March 1954).

46 Ibid. at p. 58 (diary entry, 19 March 1954). 
In my reaction to the S.G.'s proposal I had for a few days put my hope in Georges Picot. But this is a vain hope indeed. For Georges-Picot's conflict with the S.G. is too personal, too interested. And his reaction is like that of a spoilt child expressing itself more often than not against the personal character of the S.G. Since Friday I have been hammering away at the principles involved; but even if he accepts my reasoning it is because it provides him with a weapon in his personal conflict. If Hammarskjold had asked Georges-Picot to be his deputy there would be none of this carping criticism.

My feeling tor Hammarskjold is quite different. As man I like him and I am impressed by his fine intelligence. But I nevertheless feel that he is headed straight for disaster -and I would like to stop this both for his sake and for the sake of the UN. ${ }^{47}$

And, a month later:

Georges-Picot stayed with the S.G. after I left and, from what he told me later, they had a long session devoted to telling each other their truths -as the French say. The

S.G. told G.-P. that he interpreted the latter's opposition to his programme and policies as being directed against him personally -an accusation which is probably not very far from the truth! On his side G.-P. told the S.G. that he was surrounded by a group of people who were giving him only the kind of advice which they thought he wanted -"yes men", -that his proposed reorganization was ill-conceived, etc. About the Human Rights Division G.-P. said that there was really nothing new in the attack, that they had been led by the same people for over four years, and that this reorganization was being used as an occasion to give them effect. He also said that it was a strange coincidence that none of the programmes for which members of the "group" were responsible had suffered.

There was certainly food for thought for the S.G. in all this but his personal relations with G.-P. have now come to such a point that he will probably ignore the whole of it. ${ }^{48}$

By the end of the year, Georges-Picot left international service having done little to promote social affairs to the Secretary-General, and possibly much to alienate him. He was replaced by French economist Philippe de Seynes, who would enjoy a better relationship with Hammarskjöld but prove less sympathetic to the UN human rights mission.

Regarding the merger of the Social and Economic Departments, Hammarskjöld mentioned that Members of the UN had "clearly" indicated their wish that such a merger should take place. He states the rationale:

\footnotetext{
${ }_{47}$ Ibid. at p. 60 (diary entry, 23 March 1954).

${ }_{48}$ Ibid. at p. 64-65 (diary entry, 21 April 1954).
} 
[T]o ensure closer integration of economic and social activities, stronger policy direction, greater coherence in intern al programming, the more logical grouping of functions and responsibilities, the simplification of lines of authority and staff economy. 49

The overall target of the reorganization was to reduce Secretariat staff by 284 posts from 2,865 , or 10 percent, over the course of a two to three year period. Hammarskjöld was emphatic that there should be no terminations on grounds of economy. ${ }^{50}$ He therefore instituted a system in which posts were eliminated after retirement or resignation, and personnel were shifted internally as new vacancies arose. ${ }^{51}$ This policy was not, however, without its difficulties. ${ }^{52}$

While the merger of the two departments may not have been a bad idea in theory, some felt that it turned out to be so in practice. As a member of the Survey Group, Henderson had objected to the proposal that a Deputy Under Secretary position be created for social affairs, saying it was unnecessary. Humphrey reported that she later regretted the decision, when the social affairs programme suffered under de Seynes. ${ }^{53}$ De Seynes' writings confirmed a focus on the economic side of his mandate, ${ }^{54}$ which, in fairness, did have significant social repercussions as well. Hammarskjöld, with de Seynes as an ally rather than an opponent, initiated policies which gradually deflated the human rights programme for the next few years following the merger.

\section{Hammarskjöld's Actions to Deflate the Human Rights Programme}

When Humphrey protested to Philippe de Seynes about the reaction of the Sub-Commission on the Prevention of Discrimination and Protection of Minorities to the

\footnotetext{
${ }_{49}$ Report, supra note 44, at para. 10.

50 Minutes to Secretary-General's Private Meeting No. 43, supra note 42, at pp. 2 and 3. In this meeting, Hammarskjöld addressed " ... a somewhat mixed impression of the staff' reaction" and that "there were some basic misunderstandings and some unrest."
}

${ }_{51}$ Report, supra note 44, at para. 20.

${ }_{52}$ For example, it was reported a year into the implementation of the plan that shifting employees within the Secretariat was more problematic than anticipated. It was indicated at one point that the skills necessary in certain departments made it difficult to get transferees. The problem had arisen with respect to the Department of Economic and Social Affairs, in which qualifications in economic research were required. A recommendation was issued as follows: " ... in order to implement the Secretary-General's policy, departments would need to agree not to stress specialization unduly or to insist on certain individuals". (Minutes to the Secretary-General's Private Meeting No. 70 (10 June 1955), supra note 42. McGill, (comments of J.A.C. Robertson, Director of Personnel)). This approach was endorsed by the Secretary-General.

${ }_{53}$ Humphrey, supra note 4, at p. 184.

${ }_{54}$ De Seynes, supra note 36. 
Secretary-General's policies, de Seynes replied that the " ... S.G.'s policy is one of deflation and we have no alternative but to support that policy". ${ }^{55}$ Other commentators agree. ${ }^{56}$ Humphrey also related that at a private luncheon Julia Henderson, "encouraged by several glasses of champagne", stated that at the outset of the meetings of the Survey Group the Secretary-General claimed that he would like to divorce the human rights programme from the UN proper and provide the Commission with a secretariat of three to four people. ${ }^{57}$ Ralph Bunche had made a nearly identical comment on an earlier occasion. ${ }^{58}$ The deflation took the form of staff cuts considerably in excess of the overall targets, limiting the activities of the Division regarding its support for the organs of the UN, curtailing the scope of the Yearbook on Human Rights, and veiled opposition to reporting on human rights violations. These aspects are examined in detail below.

\section{Staff Cuts in the Division of Human Rights, 1954-1956}

After some two years of gradual staff cuts, Humphrey wrote a detailed Aide Mémoire on the Work Programme and Manning Table of the Division of Human Rights for de Seynes. ${ }^{59} \mathrm{He}$ noted that in 1953 the Division had, in addition to two executives and some support staff, 32 professional officers. $^{60}$ By 1956, professional posts had been eliminated. Hammarskjöld's prediction about which departments would suffer most proved to be true. While the overall target reductions to professional officer staff foreseen in the reorganization were at an average rate of 15 per cent, ${ }^{61}$ the DHR lost 30 per cent of its professional posts. Humphrey restates the justification for the cuts:

${ }_{55}$ Hobbins, supra note 24 at p. 113 (diary entry, 26 January 1955).

56 Ramcharan, supra note 21; David Forsythe, "The UN Secretary-General and Human Rights", in Benjamin Rivlin and Leon Gordenker (eds.), The Challenging Role of the UN Secretary-General (Westport: Praeger, 1993) p. 211 at pp. 223-224.

${ }_{57}$ Hobbins, supra note 24, at p. 80 (diary entry, 29 July 1954).

${ }_{58}$ Ibid. at p. 60 (diary entry, 29 March 1954).

59 The 15-page Aide-Mémoire was attached to a memorandum, Memo on the Financial lmplications of the Resolutions Adopted by the Commission on Human Rights in the matter of Annual Reports and Special Studies, 22 May 1956, located in McGill University Archives, MG 4127, Co nt. 23, File 479. The memo was sent with the attached comments of the three Section Chiefs of the Division, and thus carries their endorsement as to the truth of the comments therein. He records having sent this memo as weil as another (dealing with the Publication Board's attack on the Yearbook on Human Rights) in his diary, 22 May 1956. The other memo has not been found among his files.

${ }_{60}$ Five P-5, ten P-4, eight P-3, six P-2 and three P-1.

${ }_{61}$ Outside the Department of Conference Services, whose translation services render recruiting more difficult. See Annual Report of the Secretary-General (1954), supra note 40 at p. 4, and pp. 6-14 for a detailed breakdown of the Secretariat staff cuts. The 15 per cent figure was already 50 per cent higher than the targets planned in 1954. 
It was assumed, in particular, that (a) the draft covenants on human rights would soon be completed; (b) the activities in the field of freedom of information would be discontinued or considerably reduced; (c) there would be considerable restriction and slowing down of activities in the matter of prevention of discrimination; (d) there would be a reduction of the work relating to communications on human rights; (e) the specialized agencies, especially the ILO and UNESCO, would take over some of the work heretofore dealt with by the United Nations Secretariat; (t) the Yearbook on Human Rights would be abolished or considerably reduced in size; and $(\mathrm{g})$ there would be a reduction of the number and importance of items on human rights on the agenda of the Economic and Social Council and Third Committee of the General Assembly. None of these conditions have been realized. On the contrary, over the last two years there has been a constant and systematic increase of human rights activities on all fronts, including the items mentioned under items (a) to $(\mathrm{g}) \ldots{ }^{62}$

The rest of the Aide-Mémoire is a detailed explanation of the increase in activity, coupled with a request for an increase of nine professional officers. Humphrey had circulated the memo to the other section chiefs in the DHR, to get their comments. In the attached cover letter to de Seynes, he states that the indicated number of posts in the document was probably too low in light of the comments attached by the Section Chiefs. In particular, Lin Mousheng, Chief of Section I, states bluntly that even if the nine officers were approved, the Division's work would still be too heavy to be carried out successfully. He explains:

There are at present a total of sixteen officers in Sections land 11. If we recruit nine new officers, the total will be twenty-five. Assuming that six officers are needed for the Commission's study on arbitrary arrest, detention and exile, and six for each of the SubCommissions' studies on discrimination, there will be only seven officers left for all the other matters which are dealt with by Sections land 11: covenants on human rights, se1fdetermination, advisory services in the field of human rights, annual reports on human rights, forced labour, slavery and servitude, Yearbook on Human Rights, communications concerning human rights etc. Do you really believe that all these tasks can be performed with a degree of adequacy by seven officers only? ${ }^{63}$

Edward Lawson, Chief of Section 11, wrote that Humphrey's request for additional staff

62 Aide Mémoire, supra note 59, para. 3.

${ }_{63}$ Lin Mousheng, comments attached to Memo, supra note 59. On a much earlier occasion, Humphrey writes "I have always thought that while [Egon] Schwelb has the best retentive memory in the Human Rights Division, the most distinguished and penetrating minds are owned by Lin Mousheng and King Gordon". Hobbins, supra note 24, at p. 69 (diary entry, 18 June 1954). 
... is far below what the Sub-Commission may expect, particularly in view of the fact that [ECOSOC], in resolution $586(\mathrm{XX})$, not only endorsed its programme of work but requested the Secretary-General "to take adequate measures to provide the SubCommission with the financial and administrative assistance necessary to enable it to pursue its studies without delay". ${ }^{64}$

Mary Tenison-Woods, for Section III, confirmed that the workload set out for her section was fairly accurate, though slightly understated. Humphrey's diary breaks off until August, 1956, so there is no indication therein of the extent to which the request may have been granted.

In retrospect, Humphrey referred to three other reasons behind the reorganization cut-backs, as set forth in the report of the Survey Group: (1) the Secretariat was being asked to undertake large studies of little probable value; (2) the initiatives ask the Secretariat to encroach upon the statutory competence of the specialized agencies and (3) that there are proper limits to the scope of Secretariat action. ${ }^{65}$ These reasons are questionable. First, it would seem inappropriate for the Secretariat to make and advocate strong judgments upon the value of recommendations from UN organs acting square 1y within their statutory competence.lts role should rather be that of an executive or advisory branch. Second, the idea of not encroaching upon the statutory competence of other agencies seems excessive1y cautious, as well as imprudent. The history of the United Nations human rights programme reveals that it has expanded fruitfully when co-existing with an ever-widening number of related organs, programmes and bodies. Moreover, Humphrey states c1early that "[n]o real relief has been obtained by efforts to have the ILO and UNESCO take over part of our work and responsibility". ${ }^{66} \mathrm{He}$ points out that in one case UNESCO failed to provide any support other than an office, and that in another the minute amount of work assumed by the ILO resulted in a greater increase in ILO staff than that cut from the DHR. Finally, the comment regarding the proper scope of Secretariat action seems tenuous on its face, since Article 98 of the Charter requires the Secretary-General to perform such functions as entrusted to him by the organs of the UN, including ECOSOC and the General Assembly. Moreover, the fact that the promotion of human rights is among the purposes of the United Nations (Artic1e 1(3)) suggests that Secretariat support for those activities was well within the proper scope of its competence. Thus the rationale for the staff cutbacks was unconvincing and the cutbacks were predictably detrimental to the UN bodies supported by the DHR.

64 Edward Lawson, attached comments, Memo, supra note 63. The relevant quote from the ECOSOC resolution was drawn from a draft resolution proposed in the Report of the Eleventh Session of the Commission on Human Rights, infra note 75, at para. 57. The comments in question were directed precisely at Hammarskjöld, as the Summary Records reveal.

${ }_{65}$ Humphrey, supra note41, atp. 187.

${ }_{66}$ Aide-Mémoire, supra note 59, at para. 10. 


\section{International Conference of Plenipotentiaries, and the Ad Hoc Committee}

\section{the General Assembly, 1954}

In its tenth session, the Commission on Human Rights (CHR) concluded its work on the draft Covenants and forwarded them for consideration by the Third Committee of the General Assembly. Several suggestions were put forward on how to finalize the text. Two of the suggestions included (1) that the drafts be considered by an Ad Hoc Committee of the General Assembly, and (2) that they be finalized and adopted by an international conference of plenipotentiaries. ${ }^{67}$ In a draft Secretariat position paper, Humphrey pours cold water on the idea of an Ad Hoc Committee but recommends the international conference. His justification for support was that non-member as well as Member States could participate, thus enlarging the Covenants' purported universal character, and that " ... to such a conference governments are likely to appoint plenipotentiaries who are outstanding personalities or leading jurists and who will, therefore, enhance the value and status of the Covenants". ${ }^{6}$

Hammarskjöld replied by private memo:

By emphasizing the Draft Covenants unduly we may be weakening the force of the Declaration on Human Rights. The latter instrument has already accomplished much, while there is still much work to by done on the drafting of the Covenants, and the process of finalizing these instruments is likely to be at best a long term project. Furthermore, continuing debate on the Covenants helps to focus attention on areas of disagreement and thus to complicate the political situation. It seems, therefore, that it would be most useful to give maximum weight to the Declaration and to refrain from pressing the Covenants. I would oppose both the establishment of an Ad Hoc Committee, and the calling of a plenipotentiary conference. ${ }^{69}$

One cannot help but be impressed by the c1arity and concision of such a statement, as Humphrey was. ${ }^{70}$ However its content may be questioned. The Secretary-General did not reply to the persuasive arguments put forward by Humphrey. Also, it is by no means certain that foregoing either option would create less disagreement or expedite

${ }_{67}$ The later option being explained by the Commission on Human Rights in UN Doe. E/CNA/ L.379.

${ }_{68}$ Draft Position Paper on the Report of the Tenth Session of the Commission on Human Rights, for Item la of the provisional agenda of the 18th session of the Economic and Social Council,

McGill University Archives, Cont. 23, File 479, Section 9. Humphrey records having received the draft back with Hammarskjöld's comments, Hobbins, supra note 24 at p. 69 (diary entry, 17 June 1954).

${ }_{69}$ Dag Hammarskjöld, Memo to John P. Humphrey (16 June 1954), regarding the Draft Position Paper on the Report of the Tenth Session of the Commission on Human Rights, McGill University Archives, MG 4127, Co nt. 23, File 479, Section 9.

${ }_{70}$ Hobbins, supra note 24, at p. 69 (diary entry, 17 June 1954) where Humphrey wrote "[h]is reaction was intelligent, confident ...". 
the project. Both options were apparently put forward precisely to deal with the prospect of a long and drawn out debate in the Third Committee. ${ }^{71}$ In the event, following Hammarskjöld's decision, just such a debate took place and the Covenants were not opened for signature for another full decade. Had Humphrey's advice been followed, the UN may have side-stepped the political battles by delegating the tough issues to a conference of experts. Such a group, sufficiently far removed from the ordinary politics of the Third Committee, would have a much greater chance for consensus, not to mention flexibility of working methods and greater dedication to the issues involved. IronicaIly, this was the exact approach the Secretary-General would soon take on the issue of self-determination:

In thinking of the problem it has occurred to me, therefore, that one possible solution might be tor the United Nations to provide a forum where the question [of self determination] can be discussed in an atmosphere of calm. And for this purpose I do see some justification in setting up a new committee of a purely temporary character. For what is needed, in the first instance in any event, is agreement on basic principles -an agreement that can undoubtedly best be reached if the discussion is divorced from burning political controversies. The time of the General Assembly and of the Councils is taken up by specific problems and these problems are, most of them, highly controversial. ${ }^{72}$

The establishment of such a conference would not of course guarantee success, even if referral back to the Third Committee was avoided. ${ }^{73}$ Nonetheless a creative administrative solution could have promoted the conference in such a manner as to make the result a no-lose situation for the $\mathrm{UN}^{74}$ While it may be argued that the SecretaryGeneral was too preoccupied to deal with these various nuances, this is not convincing in light of the importance of the issues. The Covenants represented the potential for a much broader consensus upon the fundamental values of humanity than that provided by the Universal Declaration. Indeed, the respect for and promotion of such values as

${ }_{71}$ This is suggested by Humphrey in the position paper itself, supra note 68, at p. 2, or at least that the Third Committee could not possibly complete the revisions without neglecting other items.

72 Statement by the Secretary-General before the Third Committee at its 633rd Meeting, Tenth Session, Third Committee of the General Assembly, Agenda Item 28, UN Doe. A/C.3/L.466, 11 October 1955 at p. 2.

${ }_{73}$ There is a provision in the rules of procedure that allows the Conference of Plenipotentiaries to transmit the draft directly to states for ratification. This may not have been wise. Humphrey explains this provision to Hammarskjöld, supra note 68.

${ }_{74}$ For example, they could have proposed a week long conference as an "expert consultation" on the draft Covenants on Human Rights. The UN organs could play up the importance of the results of the conference in the event of a success, and play them down as a mere consultation in the event of a stalemate. 
human rights is among the primary purposes of the UN It rather seems likely that the issue was given short shrift because it had been decided firmly ahead of time.

\section{The Yearbook on Human Rights, 1955}

The report of the eleventh session of the CHR was particularly critical of Hammarskjöld. ${ }^{75}$ Humphrey, as Personal Representative of the Secretary-General, was instructed to read a statement to the Commission that was not well-received. The SecretaryGeneral stressed his belief that " ... it should be possible to reduce the bulk of the Human Rights Yearbook without diminishing its usefulness by the elimination of certain materials and by the stricter selection of items to be included in it". ${ }^{76}$ By implementing this policy, the Secretariat had already achieved substantial reductions for the preparation of the last yearbook. ${ }^{77}$ Both the ECOSOC and the General Assembly had approved this policy. He therefore asked the Commission to not press for the implementation of a 1950 ECOSOC resolution calling upon the Commission to identify rights or groups of rights as the subjects of international studies. ${ }^{78}$ The resolution envisaged the Secretariat gathering digests of legislative enactments, judicial authorities and other information on the evolution of such rights in as many countries as possible. $\mathrm{He}$ asked that this activity be dropped in order to meet the target reduction of the Yearbook and new staffing targets.

The Commission members criticized him for this approach, and unanimously adopted the provision anyway. Salvador Lopez (Philippines) stated that " ... the United Nations was now in a very real danger of pushing its concern for economy too far ... the line must be drawn somewhere and the Secretary-General should beware of budgeting essential United Nations activities out of existence ... ". ${ }^{79}$ He continued that he did not feel that the General Assembly's directives regarding financing required Hammarskjöld to reduce the UN's activities as " ... radically as he seemed bent on doing" ${ }^{80}$ Chairman

\footnotetext{
${ }_{75}$ Commission on Human Rights, Report of the Eleventh Session, UN ESCOR, 20th Session, Supp. No. 6, UN Doc. E/CN.4/719 and Corr. 1 (1955). See also Humphrey's diary entry on 15 June 1955, where the Secretary-General spoke with Humphrey about the report's criticism of him. "I explained the circumstances and said that while it was tough, it didn't reflect the full extent of the criticism that was leveled against the Seeretariat"". Hobbins, supra note 24, at p. 157.
}

${ }_{76}$ Statement Read by the Personal Representative of the Secretary-General at the Opening Meeting of the Eleventh Session of the Commission of Human Rights, UN Doc. E/CN.4/L.386, 5 April 1955 (limited distribution). The statement draws upon the more detailed Memorandum of the Secretary-General on the Review of the Human Rights Programme, UN Doc. E/CN.4/710 and Corr. 1, (1955).

${ }_{77}$ Ibid. at p. 3.

${ }_{78}$ ECOSOC resolution $303 \mathrm{H}$ (XI), 9 August 1950.

${ }_{79}$ See Commission on Human Rights, Summary Record of the Four Hundred and Eighty-Second Meeting, 6 April 1955, UN Doe. E/CN.4/SR.482 at p. 5.

${ }_{80}$ Ibid 
René Cassin (France) pointed out that since the drafting of the Covenants had just recently been finished, and as the Yearbook was gaining in popularity and use, " ... the present was an unfortunate moment to suggest that its scope be curtailed". ${ }^{81}$ Similar views were expressed by Pakistan, Greece and later by Chile. ${ }^{82}$ As Chair of the CHR Cassin twice requested a meeting with Hammarskjöld on these issues, but was rebuffed. ${ }^{83}$ Humphrey found the responses of Hammarskjöld and de Seynes to Cassin surprising, writing:

Townley [de Seynes' personal assistant] sent me today -possibly by indiscretion a copy of de Seynes' letter to Cassin. If I was shocked by the S.G.'s letter I do not know what to say of this; for de Seynes makes no attempt to hide his hostility to the human rights programme. How will all this end apart from my own utter frustration $?^{84}$

A more stunning revelation was to emerge at the next meeting. After Cheng Paonan (China) had pointed out that the CHR is one of the few that receives a specific mention in the Charter of the United Nations, Lopez began to question Humphrey about the administrative work upon the Yearbook. Humphrey mentioned that, at its then current rate without the studies on human rights, the entire Yearbook was managed by a single

${ }_{81}$ Ibid. at p. 11.

${ }_{82}$ Ibid. at 6 (Pakistan, Greece) and at the subsequent meeting by Chile and China at p. 4, Lebanon at p. 9 and Mexico at p. 10. The only countries that refuse to criticize are the United Kingdom and the United States, both of which decide to implement the resolution but use the S.G.'s remarks to push a lighter agenda.

${ }_{83}$ Hobbins, supra note 24, at p. 162 (diary entries for 15 and 16 July 1955).

${ }_{84}$ Ibid., at p. 165 (diary entry for 3 August 1955). Humphrey was so frustrated that within three weeks on 23 August (p. 170) he asked Hammarskjöld to move him out of the DHR. He wrote:

I asked Hammarskjold today to find me another job where I could make a significant contribution. I said that I was not the kind of man that he needed to implement his present human rights policy, that I had come to the UN to do an important job, that I had done it well whatever he might think of the programme, and that I was not willing to share the fate of certain officials who had become prisoners of in significant jobs and who continued to draw salaries while doing little more than routine work, if that. He seemed surprised at first and then said that he needed my "idealism" in the job. But after I insisted that I was very serious he said that the next move was his. I did not go there to argue with him about his policies and resisted the temptation to answer some of his comments. His manner was frank and friendly and in spite of my disagreement with him on so many fundamentals I could not help liking him. I compare him very favourably to Georges-Picot and, of course, to de Seynes.

I do not really expect anything to come of this démarche; but I feel better after having made it. I am never comfortable when sailing under false colours; and now Hammarskjold knows exactly where I stand. 
year-around editor, who worked with the casual assistance of other staff members. ${ }^{85}$ Hammarskjöld's plans were to eliminate this casual assistance. Lopez was astounded to hear that a job suited to four or five people was dropped upon a single person. Charles Ammoun (Lebanon), later the Special Rapporteur on Discrimination in Education, also criticized the priorities of the Secretariat. ${ }^{86}$

The CHR adopted a resolution establishing that the first study be on arbitrary arrest, detention and exile, that the second be on family rights, that the Yearbook also include a new bibliographical index, and that the Secretary-General study the possibility of publishing the Yearbook in the several official languages. Moreover, the Commission "'emphasized that' the inclusion of a new section of the Yearbook must not entail the suppression of the existing sections". ${ }^{87}$ Hammarskjöld's request was therefore completely rejected. The resolution was adopted by ECOSOC. A year later Humphrey reported that " ... the reaction of governments has been surprisingly positive and already at this early stage, only a few months after the approval of the scheme by ECOSOC in 1955, no less than 30 officially prepared contribution shave been received". ${ }^{88}$ By the time the study was published, 56 governments submitted information on the topic of arbitrary arrest and detention. ${ }^{89}$

The actions concerning the Yearbook followed a recurring pattern. The Secretary-General decided, either alone or in consultation with his inner circle, that the value of the Yearbook was limited and that its contents ought to be reduced, including the new initiatives. Since ECOSOC and the General Assembly were ambivalent and liable to pass conflicting resolutions, a skilled diplomat had the opportunity to obtain his own desired result from the debate ${ }^{90}$ Hammarskjöld forged ahead with his policies despite the fact that the Yearbook per se was not really a problem, the required resources being paltry. Furthermore, the resolution affecting the Yearbook was not a source of controversy between the Commission's Member States. The Commission was unanimous in its support for the proposed measure, and the Soviet delegate even stressed that the Yearbook was"... a form of international co-operation to bring about the extension of genera!, progressive principles in the fields covered by the Charter ... and the Universal Dec1aration ....".91 The voluntary contributions to the Yearbook,

${ }_{85}$ Commission on Human Rights, Summary Record of the Four Hundred and Eighty-Third Meeting, 6 April 1955, UN Doc.E/CN.4/SR.483 at p. 8.

86 Ibid at p. 9.

${ }_{87}$ Report of the Eleventh Session, supra note 75, at para. 32.

${ }_{88}$ Aide-Mémoire, supra note 59, at para. 11.

${ }_{89}$ Howard Tolley Jr., The U.N. Commission on Human Rights (Boulder: Westview, 1987), at p.44.

${ }_{90}$ For example, as Lopez noted, the Secretary-General did not have to interpret so narrowly the General Assembly 's instructions on economy.

${ }_{91}$ Commission on Human Rights, Summary Record of the Four Hundred and Eighty-Third Meeting, 5 April 1955, UN Doc.E/CN.4/SR.482 at p. 15. 
including the proposed studies, were initiatives which allowed different nations to share their respective experiences concerning the protection of human rights. Hammarskjöld failed to recognize that the resolutions reflected a window of opportunity to give the Universal Dec1aration and draft Covenants the wider cultural legitimacy they would need in the years to come.

\section{Studies on Discrimination, 1955}

In January of 1955, at the seventh session of the Sub-Commission on the Prevention of Discrimination and Protection of Minorities, the Secretariat was requested to assist with the preparation of a second study on the prevention of discrimination. ${ }^{92}$ After considering the Secretary-General's arguments on budgetary matters, the Sub-Commission nonetheless decided to proceed with the studies. De Seynes went personally to tell the Sub-Commission outright that the Secretariat refused to engage in a second study until the first was completed. ${ }^{93}$ Notwithstanding that position, the Sub-Commission adopted two further studies, both to be undertaken in 1956. The Secretary-General reiterated his refusal to provide assistance to the Sub-Commission for any more than one study during $1956 .{ }^{94}$ The reasons were (1) the directives of the General Assembly concerning the use of budgetary and personnel resources, and (2) the implications of the re-organization of the Secretariat. ${ }^{95}$

The Sub-Commission was less than pleased with this position. ${ }^{96}$ It adopted a resolution calling up on the Secretary-General to provide it with the necessary resources to implement the measure. ${ }^{97}$ The resolution was a compromise in that it called for the implementation of one study in 1956 followed by the other in 1957, if two in one year was impossible. This "conciliatory" amendment to the Sub-Commission's proposal passed by a vote of 10 to 8 , with stringent objections based on the principle that" ... the Commission should leave it to the Sub-Commission to determine which studies it should undertake, the order of priority and the speed at which they should be completed". ${ }^{98} \mathrm{An}$

${ }_{92}$ Commission on Human Rights, Report of the Sixth Session of the Sub-Commission on the Prevention of Discrimination and Protection of Minorities. 4 February 1955. UN Doe. E/CNA/ 711, at p.61.

${ }_{93}$ Statement to the Commission on Human Rights, supra note 76 at p. 2; see also Hobbins, supra note 24 at p. 111 for Humphrey's personal account of the affair. "There was an immediate protest and at a private meeting in the afternoon the twelve members ... prepared a draft resolution of protest ... I have every sympathy for the Sub-Commission but cannot express it, for that would be disloyalty to the S.G. whose policy de Seynes was implementing."

${ }_{94}$ Ibid.

${ }_{95}$ Ibid.

96 Hobbins, supra note 24, at p. 145 , where Humphrey points out that amid the wide criticism only Hoare (UK) and Harry (Australia) spoke in defence of the Secretary-General.

${ }_{97}$ Report of the Eleventh Session, supra note 75 at para. 57.

${ }_{98}$ Ibid. at para. 61 . 
unequivocal statement of regret was incorporated in the resolution itself. ${ }^{99}$ It was explained in the Report of the Commission:

Regret was expressed that the Secretary-General seemed to have placed budgetary considerations above the responsibilities of the United Nations in the field of human rights which the Sub-Commission was endeavouring to further ... Some members wondered whether in reality the Secretary-General's desire for economy was based solely on budgetary considerations and did not originate from fear to tread on dangerous ground. ${ }^{100}$

Presumably, the last comment referred to the very real problem of discrimination existing in all States at the United Nations, and the potential of having violations of human rights in powerful nations documented in such reports. ${ }^{101}$ On the other hand, Hammarskjöld seemed also of the view that such studies had little value, and were a waste of Secretariat resources. ${ }^{102}$ To be fair, such critical views of certain activities are not entirely foreign to Secretariat staff, including to those who are undisputedly dedicated to human rights. ${ }^{103}$ However it seems only natural that the main bodies for deciding upon the value of such initiatives are the Commission and Sub-Commission, with the Secretariat acting in advisory capacity. It would have been one thing to express doubt upon the value of such initiatives on those grounds; it was quite another to cut off the required support for the initiative.

\section{Technical Assistance for Human Rights, 1955-56}

The CHR decided at its eleventh session to adopt a resolution calling upon the General Assembly to create a technical assistance programme in the field of human rights. ${ }^{104}$ The suggested programme would be enacted in three ways: advisory services of experts; fellowships and scholarships; and regional seminars on human rights topics. The

99 The clause reads as follows: "Expresses its deep regret that notwithstanding such approval [by the Commission and the ECOSOCl the necessary steps were not taken to make such a study in 1955 possible".

100 Report of the Eleventh Session, supra note 75 at para. 59. The paragraph goes on to state a defence of the policy on the grounds that economy is important, it was initiated by the General Assembly and that it would be a dangerous precedent to give preferential treatment to some organs. A majority of members took the contrary view.

IOI See Asbjorn Eide, "The Sub-Commission on the Prevention of Discrimination and the Promotion of Minorities" in Philip Alston (ed.) The United Nations and Human Rights: A Critical Appraisal (Oxford: Oxford University Press, 1992), p. 211 at p. 216.

${ }_{102}$ Humphrey, supra note 41, at p. 200.

${ }_{103}$ Such as one of Humphrey's successors, Theo van Boven. See Theo van Boven, "The Role of the United Nations Secretariat" in Alston, supra note 10 1, p. 549 at pp. 570-71.

${ }_{104}$ Report of the Eleventh Session, supra note 75, at para. 142, Resolution VIII. 
initiative was part of a three-pronged "action programme" advocated by the United States, a renewed part of its desire to maintain its domestic liberal and progressive image after declaring its intention not to ratify the human rights Covenants. ${ }^{105}$ Regardless of the motives, it proved a boon to the human rights programme.

In his Annual Report in 1955, the Secretary-General expresses strong reservations on the use of technical assistance for human rights initiatives. He writes " ... it is doubtful whether the technical assistance approach, which has proved so fruitful in other fields, could contribute significantly to the promotion of human rights". ${ }^{106}$ The SecretaryGeneral 's representative to the Third Committee and Director of the UN Technical Assistance Administration, Hugh Keenleyside, also argued against the US proposal for technical assistance. ${ }^{107}$ Though Keenleyside and de Seynes viewed some of the changes made to the CHR resolution in the Third Committee as a victory, ${ }^{108}$ the resolution eventually adopted by the General Assembly was in fact almost identical to an early US revision of the resolution. ${ }^{109}$ Thus the amendments only helped trim the resolution back down to what its original sponsor desired.

It is noteworthy also that the Secretary -General reversed his position on the value of technical assistance by 1956 :

[At the Commission on Human Rights] I confessed to some scepticism about applying in this area certain methods usually associated with technical assistance programmes. Since then, proposals have emerged which, I now believe, may well contribute to the clarification of some human rights problems. I refer particularly to the sharing of experiences through seminars under the new programme of advisory services. ${ }^{110}$

\footnotetext{
105 So writes Humphrey in a letter to the former Assistant Secretary -General of the Social Affairs Department, Henri Laugier, in January of 1956. McGill Libraries, MG 4127, Co nt. 21, File 430. "Vous vous rappellerez sans doute l'histoire de cette résolution. Quand, pour des raisons de politique intérieure-amendment Bricker, etc.-ie State Department a déclaré son intention de ne pas adhérer aux pactes des droits de l'homme, il a fallu trouver une alternative pour faire croire aux libéraux et aux progressistes du pays qu'on faisait quelque chose aux Nations Unies pour les droits de l'homme. C'est alors qu'on a inventé cette fameuse idée d'assistance technique pour les droits de l'homme ... [Le plan américain a été adopté par une grosse majorité à l'Assemblée générale." Humphrey also mentions the criticism that the idea was attacked immediately because "under-developed "nations would never apply for such assistance insofar as such a gesture would be seen as a sign of weakness. The other two prongs of the "action plan" were annual reports and specific studies.
}

${ }_{106}$ Annual Report of the Secretary-General( 1955), supra note 32, at p. xvi.

107 Tolley, supra note 89 , at p. 35 .

108 Hobbins, supra note 24, at p. 153.

${ }_{10 " 9}$ See Report of the Eleventh Session, supra note 75, at paras. 144-145.

110 Introduction to the Annual Report of the Secretary-General (1956), supra note 22, at p. 6. 
After 1956, it appears that Hammarskjö1d gradually eased up on the human rights programme, and this statement may be one of the first manifestations of such a policy. Moreover, Hammarskjö1d seemed genuine1y concerned that controversies not mar his efforts to secure peace. In this case, the seminar programme contributed to his philosophy, as he eloquently expressed it, of moving " ... from strengths rather than weaknesses". ${ }^{111}$ It is not entirely surprising that the Secretary-General would favour an initiative in which Member States essentially show off their social achievements to one another in a mutually beneficial way. Yet his change of heart was surprising in that there was nothing substantively new about the seminar programme in 1956, despite his suggestion to the contrary. Active American endorsement of the programme may have played a role in this policy shift. Humphrey appeared to think so when he subsequently reported that de Seynes' " ... hostility to the seminars programme has been somewhat mollified by, I suspect, American pressure" . ${ }^{112}$

\section{The Self-Determination Issue, 1955}

The Secretary-General's attitude to the principle of self-determination seemed on the whole positive and supportive..$^{113} \mathrm{He}$ did, however, have relatively restrained views on how far the idea should be pushed in practice. ${ }^{114}$ In particular, he was leery of the way in which the CHR placed this issue on its agenda in 1954. That year, the CHR sought

${ }_{111}$ Annual Report of the Secretary-General on the Work of the Organization, UN GAOR, 11 th Sess., Supp. No. 1, UN Doc. A/3137/ (1956) at p. 52. The Secretary-General adds in passing here that his emphasis on the seminar programme is without prejudice to the value of fellowships and services of experts. Humphrey also expresses his doubts up on expert services comments in his letter to Laugier, supra note 105. It is nonetheless unclear why the Secretariat would not support and promote such an initiative, which is in great use today. See Advisory Services and Technical Cooperation in the Field of Human Rights (Fact Sheet No.3) (Geneva: Centre for Human Rights, 1996).

${ }_{112}$ Hobbins, supra note 24, at p. 225 (diary entry 2 June 1957). See also Humphrey's letter to Laugier, supra note 105 , in which he explains the political origins of the resolution. A more sympathetic interpretation of de Seynes' newfound warmth, however, is that he realized that the Secretary-General himself looked favourably upon the seminars. However, this interpretation is also suspect, since de Seynes' thaw occurred, according to the diaries, well after the Secretary-General professed public support for the seminars.

113 See Zacher, supra note 6, at pp. 224-225. See also the Introduction to the Annual Report of the Secretary-General (1957), supra note 17, at p. 3, where he defends the principle of one nation one vote against its critics. On the other hand, it is noteworthy that in Zacher's lengthy analysis of Hammarskjöld's methods, the principle of self-determination receives two pages of treatment.

114 Introduction to the Annual Report of the Secretary-General (1956), supra note 22, and accompanying text. While a pragmatic approach for the Secretary-General on the issue of self determination may be understandable, it does not render it immune from criticism. 
to press for the establishment of two General Assembly commissions: one would conduct a full survey of the status of the right of peoples and nations to permanent sovereignty over their natural wealth and resources, while the other would examine and report to the General Assembly any situation resulting from alleged denial or inadequate realization of the right to provide "good offices" for peaceful reconciliation. ${ }^{115}$ In a 1954 draft position paper, ${ }^{116}$ Humphrey gave reasons why the Secretary-General might wish to oppose the creation of such commissions:

In view of the possibility that the proposed commissions might duplicate to some extent the work of other organs, including the Trusteeship Council and the Security Council, the Secretary-General might not wish to recommend the establishment by the General Assembly of these two new organs. Of course, the question of the right to self-determination has been a burning political issue within the United Nations and without. Any positive intervention by the Secretary-General would have to be most judicially [sic] considered. ${ }^{117}$

Hammarskjöld's reply by memo is worth quoting at length:

The two draft resolutions of the Commission on Human Rights, referred to in the paper, impinge very clearly on the spheres of competence of the Trusteeship Council, the Security Council, the Peace Observation Commission and the First and Second Committees of the General Assembly.

A Commission to conduct a survey on the status of the permanent sovereignty of peoples and nations over their natural resources, would not only confirm the worst apprehensions of anti-United Nations groups that the United Nations is a kind of supra-national arbiter over national sovereignty; it would also tend to complicate relations among the under-developed countries and those economically more advanced.

The second draft resolution would establish a Commission which would take over a major part of the field of peaceful settlement of international disputes. There is hardly a political dispute which has been on the agenda of a United Nations organ which could not be represented as a "situation resulting from alleged denial or inadequate realization of the right of self-determination" e.g. the Iranian case, the question of Indonesia, Kashmir, the partition of Palestine, the former Italian colonies, etc. The questions of Morocco and Indochina could also be argued under that heading. The creation of such a Commission would provide a "back door" by which political questions already settled, or not inscribed on its agenda by a competent organ, could be smuggled in for consideration as "human rights" questions. This could serve only to complicate political problems.

${ }_{115}$ Commission on Human Rights, Report of the Tenth Session. UNESCOR 15th Session, Supp. No 7 UN Doe. E/CN.41705. at p. 78.

116 Draft Position Paper, supra note 68.

${ }_{117}$ Ibid at p. 3. Presumably, Humphrey meant "judiciously" rather than "judicially". 
The question is whether the Secretary-General should not actively oppose their establishment. I feel that prior consultation to this end with members of the Economic and Social Council and a statement by the Secretary-General to the Council are desirable to avoid any further confounding of all lines of jurisdiction within the United Nations. ${ }^{118}$

This is a forcefully argued position, but not entirely convincing. The argument concerning conflicting jurisdictions cannot be sustained. While Humphrey refers to the problem as "duplication", the Secretary-General refers to it as "impingement", and in his actual statement before the Third Committee two years later he uses the words "undermine their authority and jurisdiction:'119 There is nothing in the Charter reserving exclusive consideration of the issue of self-determination to the organs mentioned by Hammarskjöld. Rather, Art. 1(2) makes it a purpose of the UN as a whole to promote friendly relations among nations based on respect for self-determination of peoples. Art. 14 confirms the ability of the General Assembly to recommend measures for the peaceful adjustment of any situation, "regardless of origin", which it deerns likely to impair the general welfare or friendly relations among nations, including situations resulting from a violation of the provisions of the present Charter setting forth the Purposes and Principles of the United Nations (i.e. Art. 1) [emphasis added]. ${ }^{120}$ This provision is subject to two restrictions. The first is Art. 12 which prohibits the General Assembly from making recommendations on any matter that is before the Security Council. The second is Art. 2(7) prohibiting "intervention" in matters of a strictly internal nature. However, neither of these restrictions prevents the establishment of the proposed commissions. Art. 12 represents an exclusion of certain precisely defined issues, not a general jurisdictional bar. Art. 2(7) could not prevent the functioning of the commissions, for their work would have been analogous to the consideration of human rights violations by the CHR under ECOSOC resolutions 1235 and $1503 .^{121}$ It is also worth recalling the welcome liberties the Secretary-General took with the Charter terms governing his own office. ${ }^{122}$

${ }_{118}$ Hammarskjöld, supra note 69.

${ }_{119}$ Statement, supra note 76, at p. 2. It took two years to be considered at the Third Committee of the General Assembly. After the Secretary-General's intervention, the item was again postponed and never reappears in later annual reports.

${ }_{120}$ Article 14 is the authority cited in the Commission's draft resolution F II dealing with the alleged denials of self-determination. Report of the Tenth Session, supra note 115, at p. 78.

${ }_{121}$ ECOSOC Resolution 1235 (XLII) (1967); ECOSOC 1513 (XLVIII)(1970). For an critical overview of these procedures, see Tolley, supra note 89, at pp. 55-82; Philip Alston, "The Commission on Human Rights" in Alston, supra note 101; Henry Steiner and Philip Alston, International Human Rights Law in Context: Law, Polities and Morality (Oxford: Oxford University Press, 1996) at pp. $374-$ 420 .

${ }_{122}$ Zacher, supra note 6 , at p. 38. "His approach was based on a very liberal legal interpretation of the Charter." 
Humphrey's argument about duplication, upon which Hammarskjöld placed more emphasis in his statement to the Third Committee, is also not convincing. Irrespective of what authority it holds under the Charter, the Security Council will not generally, for political reasons, take action on issues of self-determination. Moreover it is arguable whether the Security Council is at all the logical choice for such claims, when its primary function is the maintenance of international peace and security. The General Assembly does not generally have the time or sustained interest to deal with such matters in the manner required. Allegations of denials of such rights necessitate lengthy quasi-judicial processes, and even then intergovernmental organs are reluctant to pronounce clearly upon violations. ${ }^{123}$ The Trusteeship Council was highly limited in its nature, and in any case "[t]he majority of the Commission agreed that not only the inhabitants of the Non-Self-Governing and Trust Territories, but all peoples everywhere, should have the right to self-determination". ${ }^{124}$ This raised the spectre of having a commission examine denials of self-determination outside the colonial context. The problem of a "back door" for problems already under consideration or settled could have been addressed with a simple amendment barring jurisdiction in such cases. The "duplication" argument is unconvincing since it presumed, with no real foundation, that the other UN organs were sufficient for dealing with the problem.

A more likely rationale -omitted from the statement to the Third Committee -is that the issue was simply too political. This is buttressed by Hammarsklöld's public statement in his 1956 report asking countries not to be "unrealistic" in the realization of self-determination. ${ }^{125}$ However; it is unclear how the fact that so many issues before the United Nations were problems of self-determination would have detracted from the value of a commission. Hammarskjöld may have feared that accepting the Commission would have led to a walk-out by key members of the UN, but there was no evidence that this would have happened.

It is ironic that the position taken by the Secretary-General before the Third Committee in October, 1955 was itself very controversial. Jamil Baroody (Saudi Arabia) led avocal campaign against the Secretary-General, and his comments were issued in a UN Press Release. ${ }^{126}$ Though these comments were expected and unsurprising, they were largely accurate and seemed to represent the majority view in the General Assembly. After explaining that many powers would be reluctant to sign the Covenants with the articles on self-determination, he added that this was "no excuse" for the Secretary-General, who should "never show his colours" on such apolitical question. ${ }^{127}$ Abdul Pazhwak (Afghanistan) and Father Nunez (Costa Rica) made similar

\footnotetext{
${ }_{123}$ See Philip Alston, "The Commission on Human Rights" in Alston, supra note 101.

${ }_{124}$ Report of the Eleventh Session, supra note 75 at para. 127.
}

${ }_{125}$ Supra note 22 and accompanyingtext.

126 United Nations, Department ofPublic Information, Press Release GA/SHC/4 77, 12 October 1955, Third Committee, 12th Meeting (am).

${ }_{127}$ Ibid. 
comments, and the delegate of the USSR accused the Secretary-General of taking sides. ${ }^{128}$ The reasons for such an accusation may be clarified in part by an examination of the $1955 \mathrm{CHR}$ vote on the proposed commissions, which reaffirmed the previous year's resolution: ${ }^{129}$

$\begin{array}{cl}\text { In favour: } & \text { Chile, Egypt, Greece, India, Lebanon, Mexico, Pakistan, } \\ & \text { Philippines, Poland, Ukrainian Soviet Socialist Republic, } \\ & \text { Union of Soviet Socialist Republics; } \\ \text { Against: } & \begin{array}{l}\text { Australia, France, Norway, Turkey, United Kingdom, } \\ \text { United States of America }\end{array} \\ \text { Abstention: } & \text { China }\end{array}$

Humphrey notes in his diaries that Hammarskjöld reconsidered making his statement, but was encouraged to go on and do so. ${ }^{130}$ The Secretary-General was not alone in his concern regarding the problem posed by the issue of self-determination. Cassin and Humphrey felt that the proposal to place the right of peoples to self-determination as Article 1 in both draft Covenants was a mistake. ${ }^{131}$ Indeed, Humphrey worked tirelessly to get it removed from the Covenants. Ultimately Artic1e 1 was adopted by the General Assembly, while consideration of the commissions was deferred and eventuallyabandoned. $^{132}$

${ }_{128}$ Hobbins, supra note 24, at pp. UIO-Uil (diary en try, 11, 12 and 14 October 1955).

${ }_{129}$ Report of the Eleventh Session, supra note 75, at para. 121.

130 Hobbins, supra note 24, at p. 180 (diary en try, 4 October 1955) and (diary en try, 11 October 1955).

${ }_{131}$ For Cassin, see Marc Agi, René Cassin: fantassin de Droits de I'Homme (Paris: Plon, 1979) in which the author attributes the delay of the adoption of the Covenants to the insistence by Arab states to include the right of self-determination of peoples in the Covenant. The Soviet Union, he writes, supported the initiative, which was an attempt " ... a bloquer les droits de l'homme par ce des peuples et reciproquement, pour la plus grande satisfaction de ceux qui redoutent les uns et les autres". ["to block human rights with peoples' rights and vice versa, for the satisfaction of those who dread both."] Humphrey worked with de Seynes to prepare the Secretary-General's statement on the matter of self-determination. See Hobbins, supra note 24, at p. 179 (diary entry, 3 October 1955), where he writes "I have enjoyed working closely with de Seynes on the self-determination issue. However 1 do not have any illusions: we are working for different ends, 1 to save the Covenants and he to defeat the Commission's recommendations and, 1 am afraid, in the interest of France." On 19 October 1955 (p. 182), he writes "The delegations are more concerned with selfdetermination than with human rights!" While the debate on self determination may have caused delays in drafting, the inclusion of Article 1 appears to have had no negative affect on either Covenant in terms of ratification.

132 No mention of the proposed commissions is found in the Secretary-General's annual reports for $1957-1961$. 
In October 1956 in the Third Committee of the General Assembly, the Greek delegation attempted to initiate a procedure by which violations of human rights could be addressed without having to wait for the adoption of the Covenants. ${ }^{133}$ The process began when a Greek delegation, led by Dennis Carayannis, approached the Deputy Director of the DHR, Egon Schwelb, for some advice on how to craft a proposal (Humphrey was away in the Far East at this time). In an explanatory memorandum handed to Schwelb on 16 October 1956, it was stated: "[We] hold the view that the time has come for the General Assembly to begin studies on the ways and means of filling the existing gap and preventing or at least discouraging more effectively the violations of human rights." ${ }^{134}$ The creation of a committee of experts was proposed, which under certain defined circumstances would examine situations created by violations of human rights and report to the General Assembly. It was emphasized also by the delegation that such measures would be temporary only, pending the coming into force of the Covenants. Carayannis approached Schwelb expecting that the Secretariat give some leadership to "channe1 the whole thing into proper directions". ${ }^{\mathrm{J} 35}$

Schwelb prepared a document outlining some tentative propositions for responding to the proposal. The tenor of the document is set in the following way:

The present paper is based on the idea expressed by the Secretary-General in his introduction to his Annual Report [1955]: "In carrying out its obligations under the Charter in the field of human rights, the Organization should favour initiatives leading forward without introducing the risk of sterile and endless controversy;' The ideas put forward in the present paper differ, as will be seen, from those expressed by the Greek representative. They are designed to avoid any possibility of controversial proceedings between governments acting as plaintiffs and governments acting as defendants. The Greek representative has stated that his delegation would

${ }_{133}$ Provisional Agenda, General Assembly which would provide for "interim measures, pending entry into force of the Covenants on human rights, to be taken with respect to violations to the human rights set forth in the Charter of the United Nations and the Universal Declaration of Human Rights" (A/3187). Provisional agenda, item 65 (A/3191).

134 Tentative draft of the explanatory memorandum by the Greek delegation on the proposed human rights item A/3187, McGill University Archives, Cont. 23, File 472 at p. 2.

135 Tentative propositions and suggestions concerning the human rights item proposed by Greece for inclusion in the provisional agenda of the eleventh session of the General Assembly, 15 October 1956, (author not identified in that document, but is in the memo to de Seynes described below). McGill University Archives, Cont. 23, File 472. This document was one of three documents forwarded by Egon Schwelb to Philip de Seynes on 16 October 1956, the other two being a copy of Schwelb's aide-memoire of 11 October 1956, the day on which the discussion with the Greek representative was initiated, and a copy of the Greek draft explanatory memorandum cited above. 
propose some measures of implementation which are "mild". The present paper attempts to make them still "milder". ${ }^{136}$

This paper was then forwarded to Oscar Schacter (Legal Counsel) and Constantin Stavroupolos (Director of the General Legal Division) of the Office of Legal Affairs. They believed Schwelb 's recommendations did not render it "mild" enough to be "acceptable to certain governments" and added two more recommendations. They also added that there should be no objection to Schwelb giving the Greek delegation advice on a technical level, in his personal capacity, without involving the Secretary-General. Of course it was implicit in the arrangement that Schwelb would check with the Secretary-General to ensure that it was acceptable that the latter have nothing to do with it. Schwelb forwarded a draft text of a paragraph to de Seynes, who forwarded with comments it to Hammarskjöld. De Seynes' comments are also revealing:

The Greek draft does not, of course, provide for "mild" machinery, but contemplates the establishment of an organ which would debate allegations of plaintiff governments against defendant govemments in public ... The question arises whether an attempt should be made to influence the Greek proposal with a view to make it more conform [sic] with what you said in your introduction to last year's Annual Report ... It is obvious that "sterile and endless controversy" would take place, both in the proposed committee if established, and in the General Assembly whenever its reports would be considered. ${ }^{137}$

De Seynes goes on to articulate the measures proposed for making the recommendation milder. ${ }^{138}$ According to Schwelb's memo to Humphrey, the Secretary-General

136 Ibid at p. 1.

137 Memorandum from Philip de Seynes to the Secretary-General re: General Assembly item on human rights proposed by Greece, 17 October 1956. McGill University Archives, Cont. 23, File 472, at para. 5. This memo was part ofa package of communications sent by Schwelb to Humphrey in India to keep him abreast of the developments. The letter is dated 23 October 1956. McGill University Archives, Co nt. 23, File 472.

${ }_{138}$ The suggestions were outlined in paragraph 6 of de Seynes' memo, ibid. They include the following: "(a) that the committee should not be appointed by the General Assembly but by the Secretary-General; (b) that it should not report to the General Assembly, but to the Commission on Human Rights; (c) that it should be a small committee of three or four members, comparable to the Ad Hoc Commission on Prisoners of War; (d) that the proceedings of the committee should take place in closed session; (e) that governments should have only the right to submit 'information' to the committee, not, however, complaints or allegations, and that the government which has laid the information before the committee would have no locus standi in its proceedings; (f) that apart from its decision to enter into consultation with a government, it should not be within the competence of the committee to establish whether or not a violation of human rights has occurred; (g) that the work of the committee should be restricted to consult with the 'government concerned' i.e. the accused government; (h) that if the attempts of the 
" ... expressed his high satisfaction and agreement with both the philosophy underlying the suggestions and with the substance ... " with two minor exceptions. ${ }^{139}$ However, there were clear directions from Hammarskjöld to emphasize that the Secretariat did not think it appropriate to give advice to a delegation on a matter which is so delicate, nor to influence the Greek delegation to propose milder or more radical proposals. However, when reporting back to Humphrey about the situation, Schwelb explains: "In the case the Greek delegation should make, however, the decision to propose some 'milder' machinery, then I would find no hesitation to assist Mr. Carayannis from the technical point of view". ${ }^{140}$

The Secretary-General reported in 1957 that the Greek delegation put forth two proposals: one calling for an inter-state "complaints" system described above to be monitored by the CHR, and another tor the CHR to investigate the possibility of establishing an individual petition system. ${ }^{141}$ The proposals were not accepted by the Third Committee of the General Assembly on the grounds that (1) there were no legal rules to govern the activities of the proposed committee and (2) that the CHR had already denied its own capability to deal with violations of human rights.

A few reflections on this chain of events are in order. First, it was clear that since 1947 the CHR had refused to consider violations of human rights directly. ${ }^{142}$ If the Secretariat were providing serious advice, it should have made that clear, or at least pointed out that the terms of reference of the Commission would need to be revised through the correct channels (i.e. ECOSOC). It is particularly ironic that the recommendation to substitute the CHR for the proposed expert committee was inserted by Schacter and Stavroupolos. ${ }^{143}$ Second, one could conceivably argue that the actions of

committee to assist in achieving a solution did not succeed, the proceedings would come to an end; (j) that the committee would only make annual routine reports to the Commission on Human Rights which would consider them in closed session and would respect the confidential character of the proceedings in its own annual report to the Economic and Social Council. ... [I]t is of course probable that the Greek delegation would not accept most of this advice, because they are probably interested in creating a forum where grievances could be heard publicly." The Secretary-General, in reply, expressed disapproval of item (a) and doubts about item (b). Also, Schwelb eventually included requirements of a qualified majority and non-determination of any issue falling within the competence of the Trusteeship Council.

${ }_{139}$ Memo from Schwelb to Humphrey, supra note 137.

140 Ibid.

${ }_{141}$ Annual Report of the Secretary-General on the Work of the Organization, UN GAOR, 12th Sess., Supp. No. 1, UN Doc. A/3594 (1957) at p. 81.

${ }_{142}$ For a celebrated contemporaneous critique of this position, see Hersch Lauterpacht, International Law and Human Rights (New York: Archon Books, 1950) at 229-230. The author states: "There is no legal justification for that statement. These bodies, and, in particular, the Commission on Human Rights, are not only entitled to take such action. By the terms of the Charter they are bound to do so." 
the Secretariat were an attempt to make the proposal more palatable, and thus more likely to be adopted. ${ }^{144}$ However, the record makes clear that the concern at hand appears not to be getting the proposal passed, but rather curbing what are perceived to be the deleterious effects of its implementation. Both Schwelb and de Seynes make it clear that their positions are based on the de sire to avoid "sterile and endless controversy". Moreover, de Seynes' language reveals scorn for the very idea. Third, the chain of events demonstrates the chilling effect the Secretary-General's 1956 comment had in practical matters, and his willingness to reaffirm it by highlighting his agreement with the underlying philosophy of the suggestions. A fourth reflection is that the Secretariat's proclaimed neutral stance on the issue is basically in bad faith. Schwelb is essentially told to indicate that the Secretariat will offer no support for the idea, but should go ahead and give technical advice for making the proposal milder. Finally, the suggestions would not have just have made the proposal milder; they effectively hobbled it. Experience has shown that inter-state communications, as well as confidential procedures, are not effective mechanisms for addressing human rights violations. However, it did not take experience to make such a point clear. De Seynes' reference to the reluctance of Greece to support a confidential procedure, as well as its insistence on putting forth the idea of an individual petition system, suggest that the truth of the matter was plainly in view at the time.

\section{From Hostility to Neglect, 1957-1960}

Following Hammarskjöld's unanimous re-election for another term on 26 September 1957, Humphrey began to note a change:

It would certainly be wrong to say that he has become an enthusiastic supporter of the human rights programme; but there is very real evidence of an evolution in the right direction. For example, this summer he personally corrected a paragraph which Lin Mousheng had prepared for the Introduction to the Annual Report; and by emphasizing the positive aspects of the programme showed his understanding of and sympathy with the new direction into which we are trying to steer it. ${ }^{145}$

The programme that is supported in the Introduction to the Annual Report (1957) is the US inspired "action programme". Humphrey was delighted about the seminar programme (one part of the action programme) with good reason: it was the first systematic international human rights education programme. Thus it laid the groundwork for the dissemination of human rights values in several regions of the world, ${ }^{146}$ and

${ }_{144}$ This was Humphrey's strategy with Art. 1 of the Covenants, and may be true of Schwelb's approach.

${ }_{145}$ Hobbins, supra note 24 (diary entry, 27 September 1957).

${ }_{146}$ See Myres S. McDougal and Gerhard Bebr, "Human Rights in the United Nations" (1964) 58 AmericanJournalofInternationalLaw 603, at p. 635 (who claim that dissemination was on the whole valuable and successful). 
allowed various cultures to contribute their own practices to a growing corpus of implementation techniques. This latter practice in particular may have given human rights standards cultural legitimacy and acceptance within the participating societies. Moreover, the seminars maintained some culture of human rights during a period in which the concept had lost much of its support by the Western powers, in the CHR, ${ }^{147}$ the General Assembly, ${ }^{148}$ and, of course, in the Secretariat. ${ }^{149}$ Humphrey would describe this as "keeping the flag flying". ${ }^{150}$

Humphrey's optimism may have been somewhat exaggerated. The programme was elaborated primarily under his initiative, and thus he was likely to regard it quite highly. ${ }^{151}$ There were also several concrete reasons for skepticism. As noted earlier, the programme arose as a US political counterweight to the policy of refusing to ratify the Covenants. This puts the political nature of the Secretary-General's support in clearer perspective. Moreover, "[j]ust as Western interests determined the creation of a programme to promote human rights, Western concepts of individual liberty dominated

${ }_{147}$ Alston, supra note 123, at p. 139, where he characterizes the period of 1946-1966, in so far as response to violations was concerned, as "Abdication of Responsibility"; see also Tom J. Farer and Felice Gaer, "The UN and Human Rights: At the End of the Beginning" in Adam Roberts and Benedict Kingsbury, United Nations, Divided World: The UN's Roles in International Relations (2nd ed.) (Oxford: Clarendon Press, 1993), at p. 273 who describe the Commission during this period as"... an instrument of non-protection lounging under the protective wing of ECOSOC. As proof of its existence, it summoned the energy to draft soaring standards and issue occasional reports of a comfortably general character".

14R See Edward T. Rowe, "Human Rights Issues in the General Assembly, 1946-1966" (1970) 14:4 Journal of Conflict Resolution p. 425 (for an excellent compilation of data on voting trends on contested human rights issues in the General Assembly). The author makes it clear that as General Assembly attention increasingly focuses on issues such as self-determination and racial discrimination, the western powers become less supportive of the initiatives. By 1965-1966, he records (at p. 428) that after Portugal and South Africa, the sixteen lowest scoring States in terms of support for human rights were Australia, Austria, Belgium, Canada, Denmark, Finland, France, Italy, Luxembourg, Malta, Netherlands, New Zealand, Norway, Sweden, the United Kingdom, and the United States.

${ }_{149}$ Humphrey, supra note 41, at p. 269: "The truth was ... that in those years there wasn't very much the Secretariat could do to further the human rights program apart from preparing studies and organizing seminars:'

sso Ibid.

Is Ibid. Where Humphrey mentions criticism of his emphasis on the seminars. See also Tolley, supra note 89 , at pp. 37-44, for a succinct summary of Humphrey's involvement in the programme. But see Hobbins, supra note 24, at p. 245 (Humphrey diary entry, 3 October 1957) in which Humphrey notes that "[Deputy Director Egon J Schwelb sulks because, according to his lights, the programme has go ne to pieces, the output of resolutions and draft conventions having diminished ..." This suggests that his Deputy Director did not feel as optimistic about the seminars as Humphrey did. In 1962 Schwelb resigned to teach law at Yale University. 
the first seminars and studies conducted under the programme". ${ }^{152}$ Efforts to hold seminars on topics such as discrimination, economic and social rights, internal legislative reform, as well as the effort to move from regional to international seminars failed. ${ }^{153}$ The seminars were even more politicized than this. Humphrey reports that at some time during 1957 the American delegation met with his superior ${ }^{154}$, Sir Humphrey Trevelyan, and made a request that " ... the Secretariat steer away from any Soviet participation in the human rights seminars". ${ }^{155}$ To Humphrey's dismay Trevelyan agreed, though Humphrey chose to ignore the commitment. ${ }^{156}$ As for the other branches of the action plan, the first study under the new programme still was not completed until 1961, a full six years after the proposal was first recommended by the CHR. This alone demonstrates the low amount of support given by a Secretariat noted for its efficiency. Above all, perhaps, governments would tend to host seminars only on topics about which they felt themselves to be well-advanced. Indeed, this was intrinsic to the idea of "moving from strengths, rather than from weaknesses". The obvious criticism of this approach is that human rights advocacy should seek to address weaknesses, not strengths. ${ }^{157}$ Thus while Humphrey and the US "action programme" may have kept the human rights flag flying in the late 1950s, it was kept at half-mast.

The neglect can be seen by the relative stress placed by Hammarskjöld on human rights in terms of his overall strategy. In 1956, he comments on his vision of the action plan:

The reporting system should not be allowed to develop into a vehicle for the criticism of Member States, and the studies of particular rights should not become catalogues of instances in which those rights have been violated or denied. The purpose

152 Tolley, supra note 89, at p. 37. He continues: "The Western members and their ideological allies in Asia and Latin America who controlled the Commission through the 1950s promoted a classical liberal conception of human rights:'

153 Ibid. at p. 39. One attempt resulted in the topic of reconciling economic development with individual rights, a theme th at is more a ftawed Western criticism than an endorsement of social rights. Eventually a seminar proposed by Poland in 1966 dealt with the social provisions of the Universal Declaration of Human Rights.

${ }_{154}$ Shortly before this the DHR had been transferred from the Department of Economic and Social Affairs to the Department of Special Political Affairs.

155 Humphrey, supra note 41, at p. 246. One mayalso note that Humphrey, who supported the seminars so wholeheartedly, would have had little reason to exaggerate the situation.

156 Ignoring the directive was fairly simple because Trevelyan stayed less than a year before being replaced by C. V. Narasimhan. Humphrey eventually held seminars in Hungary, Mongolia, Yugoslavia, Poland and Romania, and tried but failed to have one in Moscow or Kiev. Ibid

${ }_{157}$ For a criticism of this programme, see Farer and Gaer, supra note 147, p. 240, at p. 273. The authors comment on the Commission's " ... fierce commitment to inoffensiveness". 
of these activities should be to share experiences and techniques that help us to make more progress in promoting human rights. ${ }^{158}$

In 1957, he set forth the "Role of the United Nations" in detail, ${ }^{159}$ exc1uding any mention of human rights. ${ }^{160}$ In 1958, the Introduction to his Annual Report indicated only that ECOSOC recommended a special meeting for the observance of the 10th anniversary of the Universal Declaration of Human Rights, and that the seminars were going particularly wel1. ${ }^{161}$ The body of this lengthy document contains only two pages of information on human rights. ${ }^{162}$ In 1959 , he repeats the importance of the diplomatic and collective security role of the UN, with striking eloquence and clarity. He also shed some light on his view of human rights:

The work of today within and for the United Nations is a work through which the basis may be laid for increasingly satisfactory forms of international co-operation and for a future international system of law and order, for which the world is not yet ripe. ${ }^{163}$

This comment may provide an insight on his view of the political constraints operating in his time, granted it is addressed to a broader concern than that of human rights alone. The introduction to this report contains no references whatsoever to human rights, and the section on human rights in the body of the report is even thinner than in the previous year. No new activities are listed, except for a controversial Sub-Commission study on the right of everyone to leave any country, including his own, and to return to his country, which was primarily designed to address an Eastern bloc probIem. In 1960, his report contains a new and interesting statement:

The Organization is also the embodiment of an ideal and the symbol of an approach to international life which recognizes the common interest of all in the rejection of the use of force, in any form, as a means for settling international disputes and in adherence to the principles of law, justice and human rights ... The Organization has often in the past been faced ... with situations in which a compromise with these last-mentioned principles might seem to facilitate the achievement of results

158 Introduction to the Annual Report (1956), supra note 22, at p. 6.

159 Introduction to the Annual Report (1957), supra note 17, at pp. 3-4.

160 Rameharan, supra note 21, at p. 25.

${ }_{161}$ Introduction to the Annual Report of the Secretary-General on the Work of the Organization, UN GAOR, 13th Sess., Supp. No. IA, UN Doe. A/3844/Add.1 (1958) at pp. 5-6.

162 Annual Report of the Secretary-General on the Work of the Organization, UN GAOR, 13th Sess., Supp. No. 1, UN Doe. A/3844 (1958) at pp. 44-46.

163 Emphasis added. Introduction to the Annual Report of the Secretary-General on the Work of the Organization, UN GAOR, 14th Sess., Supp. No. IA, UN Doe. A/4132/Add.1 (1959) at pp.2-3. 
in negotiations or to promise an easier success for the Organization in its executive efforts to resolve a problem ... It is my firm conviction that any result bought at the price of a compromise with the principles and ideals of the Organization, either by yielding to force, by disregard of justice, by neglect of common interests or by contempt for human rights, is bought at too high a price. ${ }^{164}$

These words provide a remarkable contrast with Hammarskjöld's other comments and actions concerning human rights, particularly his constant concern to avoid "controversial problems". There would appear to be two possible explanations for this volte face. The first, doubtful at best, is that the Secretary-General's attitude towards human rights had fundamentally changed during the prior year. The second is that he had political motives. Ten days after presenting his report, "Hammarskjöld made a speech in the Security Council in which he referred to 'flagrant violations of human rights' in the Congo". ${ }^{165}$ Thus Hammarskjöld's most straightforward statement in support of human rights coincided with his strategy to use human rights violations to justify his most highly criticized politicalintervention. ${ }^{166}$ The following year, Hammarskjöld would come out almost directly against the Soviet Union in his annual report, and put enormous emphasis, for the first time, on how Article 55 of the UN Charter requires more than amoral conciliation and conflict resolution. Rather, he argued, Art. 55 requires concrete action for the rights of individuals as well as States, and that those who fail to see this " ... do not pay adequate attention to those essential principles of the Charter .. ". ${ }^{167}$ $1 \mathrm{t}$ would seem that by these words, the Secretary-General has sown the seeds of a robust critique of his own attitude towards the human rights programme during the early part of his term.

The 1961 report came at a time when there was open hostility between Hammarskjöld and the Soviet Union. The latter had refused to deal with the Secretary-General over what it perceived as his open involvement in advancing US foreign interests in the Congo during the operation known as Organisation des Nations Unies au Congo

${ }_{164}$ Introduction to the Annual Report of the Secretary-General on the Work of the Organization, UN GAOR, 15th Sess., Supp. No. IA, UN Doc. A/4390/Add.1 (1960) at p. 7.

165 Humphrey, supra note 41, at p. 270. The speech was delivered on 10 September 1960.

$1661 \mathrm{t}$ is not uncommon for States to use human rights violations, somewhat cynically, to justify certain acts of foreign policy. The best account of such practices, though dated, would be Noam Chomsky and Edward S. Herman, The Political Economy of Human Rights: Volume 1 \& 2: The Washington Connection and Third World Facism (Boston: South End Press, 1979) at pp. 32-40 (Vol. 1) for a short summary. The authors go much further than showing a "disregard" for human rights; rather, they demonstrate active financial and military support for regimes that were known violators. For a more recent accounts, see Rein Müllerson, Human Rights Diplomacy (London: Routledge, 1997) at pp. 105-117; Tony Evans, US Hegemony and the Project of Universal Human Rights (New York: St. Martin 's Press, 1996).

167 Introduction to the Annual Report of the Secretary-General on the Work of the Organization,

UN GAOR, 16th Sess., Supp. No. IA, UN Doc. A/4800/Add.1 (1961) at pp. 1-2. 
(ONUC). ${ }^{372}$ Recent research has confirmed this allegation to be true. As early as 1966 it was recognized, by involved Secretariat officials, that the personnel in the ONUC operation consisted of"... an inner core of Americans around Hammarsjkold, with an outer-casing of neutrals". ${ }^{169}$ Indeed, the chief Secretariat officials involved in overseeing the operation, Ralph Bunche and Andrew Cordier, were both former US State Department officials before joining the Secretariat. As Gibbs demonstrates extensively:

[D]eclassified documents leave no doubt that Hammarskjöld and other UN officials were intervening in the Congo, that they were doing so intentionally, that they were actively collaborating with Western officials in the course of these interventions, and that these actions were salutary for US foreign policy objectives. ${ }^{170}$

At one point, the Secretary-General told a US official that he " ... was trying to get rid of [Patrice] Lumumba without compromising the UN position and himself through extraconstitutional action". ${ }^{171}$ In another case, on 8 August 1960, a few weeks before the Secretary General submitted his report to the General Assembly, Henry Cabot Lodge reports to the US Government that "Hammarskjöld had made a very strong statement today" regarding the Congo issue and that "frankly" he himself "had assisted Hammarskjöld in writing it". ${ }^{172}$ Suffice it to say, despite the rhetorical references Hammarskjöld made to human rights in the last few years of his tenure, they may hardly be counted upon as demonstrating his reverence for the purposes and principles of the Charter. Rather, they fit neatly into a plan of advancing one particular strategic objective, which ironically led to one of Africa's most disastrous human rights records. ${ }^{173}$

\footnotetext{
${ }_{16 g}$ Urquhart, supra note 1, at pp. 389-493, particularly Chapter 17.

${ }_{169}$ Conor Cruise O'Brien, To Katanga and Back (New York: Universal Library, 1966) at p. 56.
}

170 David N. Gibbs, "The United Nations, International Peacekeeping and the Question of 'Impartiality': Revisiting the Congo Operation of 1960" (2000) 38:3 Joumal of Modern African Studies 359 at 372; see also Carole Collins, "Fatally Flawed Mediation: Cordier and the Congo Crisis of 1960" (1992) 39:3 Africa Today 5, in which the author argues that Cordier's actions tueled the civil war, compromised the neutrality of the UN, led to the death of Patrice Lumumba and funded the rise of the infamous dictator, Mobutu Sese Seko.

171 Gibbs, ibid. at p. 55, referring to official documents in Foreign Relations of the United States, 19581960: Volume 14: Africa 1992 (Washington, DC: US Government Printing Office, 1992).

${ }_{172}$ Gibbs, ibid. at pp. 369-370, paraphrasing from US Government. 8.8.60. "Telephone Calls, Monday", Christian A. Herter Papers, Telephone Calls Series, Box 13, Eisenhower Library. Abilene, Kansas.

173 That the UN assisted Mobutu's rise to power, and even that Hammarskjöld was personally involved by facilitating Cordier's efforts, is demonstrated beyond doubt by Gibbs. For a description of Zaire 's dismal human rights record, explained in tandem with US bilateral and military assistance to the country, see Makau Mutua and Peter Rosenblum, Zaire: Repression as Policy (New York: Lawyers Committee for Human Rights, 1990), excerpts of which appear in Henry Steiner and Philip Alston, International Human Rights Law in Context: Law, Polities and 


\section{Justifications}

Hammarskjöld had justifications for particular acts regarding the human rights programme. These tended to relate to the general question of economic problems and political difficulties. These rationalizations do not appear entirely satisfactory upon closer scrutiny. There were clearly other additional and unstated factors involved.

\section{Economie Problems}

In Hammarskjöld 's statement to the CHR at its eleventh session (1955), economy was a significant reason advanced for the cuts to the Yearbook and the refusal to continue new studies on discrimination. ${ }^{174}$ It is absolutely clear that the CHR viewed this argument as the chief concern. ${ }^{175}$ Yet Hammarskjöld indicated to the General Assembly that economy was not the chief goal of the reorganization plan:

Budgetary savings however will emerge as a by-product of the reorganization process rather than as ends in themselves. The review had as its primary aim a reassessment, in consultation with the other organs concerned, of the role which the Secretariat can most constructively play in furthering the objectives of the Charter, and, in this context, the nature and scope of the activities it can most usefully undertake were reappraised. ${ }^{176}$

This is buttressed by his comments in the introduction to the 1955 annual report, in which he writes that the "... primary purpose of making the Secretariat a more efficient and flexible instrument of the United Nations has continued to motivate all decisions of detail affecting organization". ${ }^{177} \mathrm{He}$ adds that the functions of the Secretariat have been reappraised in order to strengthen " ... those areas in which its most constructive contribution can at present be made". Thus economic savings were considered an incidental by-product of rationalizing the work of the organization along new priorities. This view of priorities was, in some cases, stated explicitly. On 20 May 1955 Keenleyside addressed other high level officials about the notion of freedom of information during the SecretaryGeneral's private meeting. The minutes read as follows:

Morality (Oxford: Oxford University Press, 1996) 839. The authors refer to the US strategic interest in copper, cobalt and geographic location to the country, and to President Ronald Reagan 's reference to Mobutu in 1984 as " ... a faithful friend for some 20 years".

${ }_{174}$ Statement, supra note 76 and accompanying text.

175 This is clear in the Summary Records and the Report of the Eleventh Session, supra note 75.

176 Report, supra note 44 , at para. 3.

177 Report, supra note 32, at p. xvi. See also Statement made by the Secretary-General at the 443rd meeting of the Fifth Committee on 22 October 1954, in UNGAOR, 9th Sess., Annexes, Agenda Item 53, UN Doe. A/C.5/591 (1954) at paras 35-38,in which he answers questions as to why the economies were not taken further. He also gives admirable concern to the needs of developing countries. 
Mr. Keenleyside referred to the consideration of the question of freedom of information by the Social Committee. He had made a statement along the lines he had previously agreed with the SecretaryGeneral. Mr. Keenleyside's main point was that for the past five years, Technical Assistance efforts had concentrated on three major fields: economic development, social welfare and public administration. It was disproportionate to place the freedom of information on the same level as these fields of work ... The Secretary-General thought that the views expressed by Mr. Keenleyside were solidly shared by members of ECOSOC. ${ }^{178}$

The reasons for deflating the human rights programme were never fully explained in the SecretaryGeneral's statement to the Fifth Committee of the General Assembly ${ }^{179}$ (which handles budgetary matters) nor in his report to the plenary meeting of the General Assembly. ${ }^{180}$ This is surprising in view of the importance given to the promotion of human rights in Artic1e 1 of the Charter contrasted with the fact that the professional staff of the DHR was cut twice as much as the Secretariat average. The carefully circumscribed justification of economy fails to explain the disproportionate deflation of the programme. It seems rather that the de-emphasis took place because human right was not a priority in Hammarskjöld's vision of the proper uses of the Secretariat.

\section{Political Difficulties}

On 15 June 1955, the Secretary-General called Humphrey up to his office to discuss, among other things, the report of the eleventh session (1955) of the CHR. Humphrey explained that the report did not reflect the full extent of the CHR's criticism of the Secretariat. Hammarskjöld replied that his " ... attitude towards the human rights programme was determined by his concern for bigger issues". ${ }^{181}$ This is quite consistent with his other statements in his annual reports examined above. He viewed the $\mathrm{UN}$ as a forum in which differing viewpoints could meet and build bridges of cooperation, not fortify intransigent positions. Thus it would be counter-productive to occupy the time of the United Nations with political battles, which were, in his opinion, "sterile and endless" anyway. The topic -self-determination-was so controversial that he"... did not want the subject to interfere with his efforts to mitigate more conventional conflicts threatening peace and security". ${ }^{182}$ It is also suggested that "he had so much on his shoulders, and he built up so much that was new in the area of international peace and security that it would be unrealistic to have expected him to be simultane

${ }_{178}$ Minutes of the Secretary-General's Private Meeting No.68, supra note 42, at p. 2. 179 Ibid.

180 Report, supra note 40.

${ }_{181}$ Hobbins, supra note 24, at p. 157 (diary entry, 15 June 1955).

${ }_{182}$ Forsythe, supra note 56, at p. 224. 
ously creative on all fronts". ${ }^{183}$ There is a fair amount of support for such apolitical interpretation of the Secretary-General's mandate in the Charter itself. Other Directors of the DHR have recognized the importance of this function of the Secretary-General, and the difficulty that would be presented if the Secretary-General were to implicate him or herself directly in political matters. ${ }^{184}$ To do so may compromise the office's neutrality, a matter of cardinal importance.

These arguments may explain Hammarskjöld 's tendencies, but do not really justify the deflationary actions. First, such matters as the Yearbook, studies in human rights, and seminars were not controversial when proposed, but were still resisted by the Secretary-General from the outset. Second, his attack on the programme was largely complete before his significant involvement in diplomatic activities developed ${ }^{185}$ and, indeed, his attitude towards the programme softened as he became more active in political affairs. Third, it is not clear that any of the proposed initiatives would have interfered with peace-making activities, even the Greek proposal for a system of complaints. That particular system would simply have been embarrassing for individual States. In fact, the proposed modality of an interstate system would have given more opportunity for controversy than an individual complaints system. It was no doubt proposed because people knew that it would not likely be used often in such a format. Fourth, his willingness to suppress the programme was itself viewed as controversial at the time, although chiefly by representatives of the developing world.

It is also important to present what may be characterized as the "idealist" argument. ${ }^{186}$ No Secretary-General ought to leave aside the advocacy of human rights, not only because there is a UN Charter obligation to promote them but also because it is improper to compromise them for pragmatic reasons. Hammarskjöld himself stated

${ }_{183}$ Ramcharan, supra note 21, at p. 26. It should be noted that Ramcharan published this book two years before Humphrey wrote his autobiography, and without the benefit of Humphrey's edited diaries. Thus the details of the Secretary -General's actions as recalled by Humphrey were not available at the time of publication.

${ }_{184}$ See Van Boven, supra note 103, at p. 556.

${ }_{185}$ Commentators point out that the Secretary -General only realized his potentialities after 1955 or 1957. Urquhart, supra note 1, at p. 131, where he writes "[The Peking experience 1stimulated in him a new taste and new ideas for using his office and his position to tackle difficult problems ... After August 1955 his style changed noticeably, as if, at the completion of the affair of the American prisoners in China on his fiftieth birthday, he had come of age as Secretary -General:' One may note that the major problems discussed above had occurred in 1954 and 1955, with a gradual thaw thereafter. Rovine, supra note 19, at p. 330, places the development a bit later, at around 1957.

${ }_{186}$ Hammarskjöld once referred favourably to Humphrey's idealism as an asset to his job. On the general effect of ideas on the evolution of practices, see Kathryn Sikkink, "The Power of Principled Ideas: Human Rights Policies in the United States and Western Europe", in Judith Goldstein and Robert O. Keohane (eds.), Ideas and Foreign Policy: Beliefs, Institutions and Political Change (Ithaca: Cornell University Press, 1993). 
" ... that the international civil servant cannot be accused of lack of neutrality simply tor taking a stand on a controversial issue when this is his duty and cannot be avoided". ${ }^{187}$ Later in the same lecture, he continues: "[T]he responsibilities of the Secretary-General under the Charter cannot be laid aside merely because the execution of decisions by him is likely to be politically controversial". ${ }^{188} \mathrm{He}$ has made precisely the same kind of argument with respect to the role of the UN in his 1961 report, with explicit reference to human rights. ${ }^{189}$ Even if a political realist would retort that this argument is false or naïve, it is at least clear that Hammarskjöld himself professed to hold such an opinion. At best one could argue that these principles would be effectively served by his deflationary actions, in view of the desires of the Great Powers at the time. However, this would require showing that Hammarskjöld would have put his office and other efforts in jeopardy by merely allowing the programme to develop at its natural pace or by letting other Secretariat officials encourage new activities. No evidence has suggested that this would have been the case. Indeed, it appears that his early actions were without great extern al pressure. If anything, he risked more by coming out against the studies on discrimination and the issue of se1f-determination, since this invited predictable suspicions of partiality. As with the economic arguments, political concerns do not provide a valid justification for the deflation.

\section{Other Unstated Factors}

The other unstated factors may be summarized as Hammarskjöld's management style, his personality, the influence of his trusted advisors and the philosophical concept of idealism versus realism.

\section{Hammarskjöld's management style}

Hammarskjöld's own management style may have shaped his attitude towards the human rights programme to some extent. He showed an apparent de sire to manage directly, or through his c10sest advisors, even the minutest detail in the Secretariat administration. The direct consequence of such a policy is to make the activities of the various bodies in the Secretariat attributable directly to the office of Secretary-General. The corollary is that the Secretary-General would be, or at least feel, officially accountable for all activities. Thus the perceived political limitations of the office of the Secretary-General would be imposed upon the human rights programme.

While serving as Acting Assistant Secretary-General of the Social Department, Humphrey attended the Secretary-General's regular private meetings for ASGs. ${ }^{190} \mathrm{He}$

187 Dag Hammarskjöld, "The International Civil Servant in Law and Fact: Lecture Delivered in Congregation at Oxford University, May 30, 1961", in Cordier and Foote, supra note 43, Volume V (1960-1961),477 at p. 488.

188 Ibid. Note that in this case, the Secretary-General is speaking directly about his obligation to carry out the mandates entrusted to him by resolution by the political organs of the UN.

189 Introduction, supra note 167, and accompanying text.

${ }_{190}$ Hobbins, supra note 24, at p. 71 (diary entry, 25 June 1954). 
reported that the question of restricting programmes based on the Secretary-General's own limitations was raised. Victor Hoo, Assistant Secretary-General for the Trusteeship Department, drew attention to a passage of the Secretary-General's annual report to the General Assembly in which the following was written:

[T] he very nature of the responsibilities that must be assumed by the Secretary-General and his senior staff imposes a limit of the volume of the tasks that can be handled effectively, irrespective of the additional funds, personnel and facilities that might be placed at their disposal. That is to say, for a body such as the Secretariat, with its necessarily centralized structure, there exists an optimum size which is desirable if it is to be efficient and effective in the dynamic development of the activities of the Organization ... This forces the organs to make a choice between urgent and less urgent projects. ${ }^{191}$

Hoo's concern was with the belief that the limitations of an effective Secretariat were imposed by what the Secretary-General and his immediate staff could personally oversee. Humphrey notes that " ... he got a quick answer and beat a hasty retreat". ${ }^{192}$ Humphrey privately criticized this approach as " ... the failure ... to understand that a sine qua non of public administration is the delegation of power and responsibility". ${ }^{193}$ This was not the only time attention had been drawn towards a tendency to adopt a firm and potentially exclusive role on management issues. For example, the decision in 1957 to transfer the DHR from the Department of Economic and Social Affairs to the new Department of Special Political Affairs was taken without any consultation with the Director. ${ }^{194}$ In another case the Advisory Committee on Administrative and Budgetary Questions suggested to the Secretary-General that the membership of the Survey Group on Reorganization be broadened to include outside expertise. ${ }^{195}$ The Secretary-General cast doubt on the merits of the request, and asked for the latitude to decide the issue himself. ${ }^{196}$ Even top ranking staff members were not given much chance to exam

191 Annual Report of the Secretary-General (1954), supra note 40, at p. xv.

192 Hobbins, supra note 24, at p. 71 (diary entry, 25 June 1954).

193 Ibid. at p. 67 (diary entry, 23 May 1954).

194 Humphrey, supra note 41, at p. 241. He mentions that he found out through a press conference. Humphrey adds that news of the transfer was "welcome", likely due to his increasingly open conflict with de Seynes.

195 Sixth Report of the Advisory Committee on Administrative and Budgetary Questions, in UNGA, 9th Sess., Annexes, Agenda Item 53, UN Doc. A/2745, (1954) 15, at p. 19.

196 Statement made by the Secretary-General at the 443rd meeting of the Fifth Committee on 22 October 1954, supra note 175, at para. 42. "[In declaring my willingness to uphold the request] I should not like to have my hands tied in the sense that I would have to add some kind of outside expertise if I were personally convinced that, with the people I could get, that really would not help the operation, or might prolong it ... If there is a way in which I feel that this operation can 
ine and report upon the 1955 report of the Survey Group before its finalization. ${ }^{197}$ Humphrey remarks several times about the more petty elements of the controlling nature of the administration. ${ }^{198}$

In May 1955, while the Secretary-General's hostility to the idea of technical services in the field of human rights was still intact, an exchange between him and Ahmed

S. Bokhari supports further the point made here. ${ }^{199}$ Bokhariclaimed that a large number of Asian countries would tend to support Technical Assistance in this field, and that the tendency would increase in the next five years. "The lack of funds would not deter the recipient countries from supporting the programme, since they felt that this was their right". The Secretary-General's response was recorded as follows:

The Secretary-General felt that representatives of these countries should be reeducated. Promotion of freedom of information was a perfectly proper United Nations activity, but it should not be put under the Technical Assistance label. The Secretariat should be left free to organize it in the proper way. Some of the supporters of the programme had got on the wrong ferry-one that goes to the factory, not to a high school, ${ }^{200}$

be strengthened and made more efficient, I will be glad to take it. But I am not sure that there is. Under such circumstances, I would be happy if in this case you trusted my judgment:'

198 Minutes to the Secretary-General's Private Meeting No. 76, 2 September 1955 at 9:30am, supra note 42. "Mr. Bunche, replying to a question by Mr. Bokhari, said that the report of the Survey Group was in its final stages. The Group was trying to work out some rational conclusions regarding the Information Centres. Mr. Bokhari offered all assistance to the Survey Group in its consideration of that problem. He hoped that he would have an opportunity of seeing the Survey Group's report before it was finalized. This was agreed." Ahmed S. Bokhari was the the Under-Secretary-General of the Department of Public Information. His deputy Under-Secretary, Alfred G. Katzin, was himself a member of the Group.

198 Hobbins, supra note 24, at p. 57 (diary entry, 18 March 1954) "[T1he Secretary-General ... has consistently ignored my function and title [Acting Assistant Secretary-General of Social Affairs]. I do not think that the reason for this was my mere acting capacity; for other assistant secretaries general apparently receive the same treatment ... The reason is th at Hammarskjöld does not want to share his authority in any way ... He is a man who is sure of himself and who has apparently usually been right." See also Hobbins, supra note 24, at pp. 98-99 (diary en try, 22 October 1954), where he mentions that nothing could be done in the Secretariat without express approval of the Secretary -General.

199 Minutes to the Secretary-General's Private Meeting No.68, supra note 42, at p. 3.

200 Ibid. Later in the same meeting, Bokhari raised the question of whether the Advisory Committee on Administrative and Budgetary Questions had the authority to set a ceiling on ECOSOC participants. "The Secretary -General said that it was not normal for the Advisory Committee to set any ceiling on staff, but in this particular case he agreed with them:' He went on to justify the policy decision and the issue was thereafter dropped. 
De Seynes would later confess that one drawback of the time was the view that the Secretariat could and should be run by "enlightened Westerners", a view that fits well with the some of the tendencies reviewed here. ${ }^{201}$

\section{Hammarskjöld's personality}

Hammarskjöld's incredible intellectual capacities and the personal disposition contributed to his management style, and he expected others to keep up with his own mental quickness. "Failure to keep pace could cause him to make harsh judgments. His job always came first, and any attempt to infringe on this priority would incur his extreme resentment." ${ }^{202}$ There were similar views of his impatience. ${ }^{203}$ The image of the impatient and demanding genius is a familiar one. A consequence of such personalities is often the desire to regulate things oneself, or to entrust them only to people with similar capacities and with whom one has a personal connection. This profile fits well with the practice of the Secretary-General.

The consequence such a practice had on the UN human rights programme was significant. An alternative approach to organizing the UN Secretariat would be to give the various heads and directors of different departments a stronger role in the administration of their respective programmes. ${ }^{204}$ This was much the approach of Trygve Lie towards the human rights programme, as well as the former Assistant Secretary-General for Social Affairs, Henri Laugier, and Hammarskjöld 's successor U -Thant. ${ }^{205}$

${ }_{201}$ De Seynes, supra note 36, at p. 74. "Something has to be said here about our mentality as 'enlightened westerners' devoted to the cause of the Third World. At the beginning, we thought that 'Western enlightenment' would bring to the Secretariat adequate credentials. It took us some time to understand that the geographic distribution of posts as a strong requirement ... Perhaps in the Hammarskjöld period we were slow in redressing the initial imbalance ..."

202 Urquhart, supra note 1, at p. 28.

${ }_{203}$ See Cordier, supra note 25, at pp. 16-17, where he describes the following incident. "On one occasion, at the conclusion of a meeting at four o'clock on Sunday morning, he asked a delegate to come to his office at ten on the same morning. The delegate responded that he had to have some sleep. Hammarskjöld stamped up and down in the corridor outside his office repeating 'Sissy, sissy. The man has to sleep! 'We never allowed him to forget the slight impulsiveness. He soon joined in the humor of it all." One must note that this incident took place at the height of the Suez crisis, during which time Hammarskjöld often worked around the clock. Whether this alone can explain such an outburst is something for speculation.

${ }_{204}$ Van Boven, supra note 103, at p. 573. "[Successive Secretaries-General have not taken a keen interest in the human rights programme and as a result a great deal of room has been left to the Director, perhaps not so much by way of express delegation of authority but rather by the inclination of the Secretary -General not to get too involved in human rights matters." The discretion was not the case for Humphrey at the outset of Hammarskjöld 's term, as noted in his diary.

205 See Humphrey, supra note 41 , for a description of the years in which this attitude was prevalent. In particular, see pp. 103-107 for a single example of the close collaboration between him and Laugier. 
Even Laugier's successor, the economist Georges-Picot, who had no particular interest in the work of the DHR, left Humphrey exceptional latitude in running it and consulted him on important decisions. Theo van Boven explains the impact of the different approaches:

Some staff members who are further removed from the political centre of the Secretariat and more directly in touch with human rights problems, may wish to see more visible action. As long as a Secretary-General insists on a uniform, centralized approach by the entire UN administration, neutrality and caution will inevitably be the watchwords on all levels. ${ }^{206}$

The implications concerning Hammarskjöld are clear. His tendency to manage c10sely all aspects of the Secretariat implied a dislike of any policies that he believed brought political controversy. The ultimate question is whether it was necessary or desirable to insist on a modus operandi that led to the Secretary-General's implication in human rights matters. It would appear that it was not necessary, but was in part a consequence of his personality and administrative preferences.

\section{The Influence of Hammarskjöld's Aides}

Hammarskjöld's opinions were quite likely influenced considerably by his c10sest collaborators at the UN. The highly detailed and busy schedule of the Secretary-General would necessarily require reliance on aides for quick decisions. Cordier recalled the degree of collaboration between the two.

My office was separated from his only by two secretarial offices. Every day he came frequently to my office or I went to his to exchange views and to expedite business. We were constant luncheon companions for eight and a half years, and the call of work almost always brought us together on Saturdays and Sundays ... He made every matter of concern to him as SecretaryGeneral also a matter of concern to me. ${ }^{207}$

Cordier maintained his contacts with his former employer, the State Department, and Humphrey even relied on this for his own quiet diplomacy. ${ }^{208}$ Others report that Cordier was a "pivotal" figure in the administration, and was also " ... the originator of a great deal of policy himself". ${ }^{209}$ This ongoing contact was used to advance US foreign inter

206 Van Boven, supra note 103, at p. 556.

207 Cordier, supra note 13, at p. 1.

20g Humphrey, supra note 41, at p. 105. "Having gone this far, I decided to talk to Andrew Cordier, the executive assistant of the Secretary-General, who I knew was in close touch with the state department." Cordier later discussed it with the American mission.

209 Larry Trachtenberg, "A Bibliographic Essay on Dag Hammarskjöld ", in Dag Hammarskjöld Revisited, supra note 36 , p. 149 at p. 164. 
ests as confirmed by the declassified documents on the ONUC operation. ${ }^{210}$ However, the policies of the Secretary-General were not always consistent with those of the US, and he was backed up by Cordier in some of these rifts. ${ }^{211}$ Therefore the evidence suggests a high but not absolute degree of collaboration, and significant US influence is probable.

Cordier's opinions of human rights are not known. However, two observations are relevant. First, the US Bricker Amendment meant clearly that the US would not sign the Covenants on human rights. If the Covenants were adopted and ratified widely, they would be a stain on the US record. This is particularly so since the US was the delegation that insisted that human rights be included as among the purposes of the $\mathrm{UN}^{212}$ and was a crucial participant in the drafting of the Universal Declaration of Human Rights. ${ }^{213}$ This may be added to the fact that the Secretariat's attitude on the whole to human rights was quite consistent with US foreign policy, with a few minor exceptions. ${ }^{214}$ While at the moment no proof of direct influence by Cordier on human rights matters has surfaced, the totality of factors suggests a relationship between Secretariat attitudes and US interests, perhaps mediated in part through Cordier. The second observation was that Cordier and Humphrey had bad relations. In 1950, weIl before Hammarskjöld's arrival, Humphrey had told Cordier that he believed that the Human Rights Covenant ${ }^{215}$ was being ruined by excessive US prudence. He sent Cordier an eight -page memo detailing some of the pro blems. The contents of the memo were later adopted by theAssistant Secretary-General Henri Laugierin a public speech to a group of NGOs. This speech was later taken up in the CHR, making the US representative, Eleanor Roosevelt, furious. Cordierwas annoyedand upset by the situation. ${ }^{216}$ Humphrey records two other incidents which in themselves were of minor importance, and concluded that his poor relations with Cordier may have explained in part his problems with Hammarskjöld. It is difficuit to imagine Cordier sabotaging the human rights

${ }_{210}$ See Gibbs, supra note 170.

${ }_{211}$ See Urquhart, supra note 1, at p. 94. The reference is to the disagreement on the Guatemala affair. In fact the issue involved the Secretary-General opting not to contest the US position officially before the Security Council, but to express it as an opinion later, by private memorandum. He was chastized for expressing this opinion.

${ }_{212}$ McDougal and Bebr, supra note 146, at p. 612.

${ }_{213}$ Mary Ann Glendon, A World Made New: Eleanor Roosevelt and the Universal Declarationof Human Rights (New York: Random House, 2(01).

214 The few exceptions being the technical assistance for Freedom of Information, which was adopted anyway, and the initial but later retracted disapproval for technical assistance for human rights.

215 At this point in time there was still to be only one human rights covenant, expressing social and civil rights together as an affirmation of their indivisibility. It was due primarily to strong western objections that the single covenant was split into two.

216 Humphrey, supra note 41, at pp. 105-107. 
programme due to his dislike of its Director, even if this were true. However, it may have had a bearing on how much latitude he would advise the Secretary-General to accord the Director, and how much credence to give to his suggestions.

Another key advisor of the Secretary-General was Ralph Bunche. Bunche served as UnderSecretary-General without Portfolio, a post to which high level ad hoc assignments were delegated. Bunche was a critical figure in the reorganization of the Secretariat and the leader of several peacekeeping missions. Humphrey explains Bunche's attitude towards human rights in a meeting at the Secretary-General's office in which Hammarskjöld, Bunche, de Seynes, Stavropolous and Humphrey discussed the issue of self-determination:

[I] was shocked by Bunche. Not only was he the most conservative-perhaps reactionary would be a better word -pers on there; but he seemed unable to grasp essential points. I was very much annoyed by his attitude towards the Covenants and showed it. He said that there was no problem because they would come into force anyway. To which I replied that it was our job to see they were made acceptable so that they would come into force. Coming down the hall later, he attacked the Commission on the Racial Situation in South Africa as a waste of time. ${ }^{217}$

Humphrey's strong opinions likely derive from his high estimation of the Covenants. Hammarskjöld considered Bunche to be one of the "greatest negotiators of our time" and kept him close as an advisor and personal friend. ${ }^{218}$ Again, Bunche's attitudes, if true, may have refiected US approaches to human rights at the time. $\mathrm{N}$ evertheless there is little support outside of Humphrey's comments for a claim that Bunche opposed the human rights programme at the UN The only corroboration is the fact was that he appeared to be the official in charge of the S UIvey Grou p that recommended the dras tic downsizing of the DHR.

Hammarskjöld also greatly respected de Seynes, who was, according to Humphrey, more hostile to the hu man rights programme than the Secretary-General himself. De Seynes was an economist, and likely less concerned about the politicized issues of human rights when compared with the potential for good through development aid to underdevelopedcountries. He also had astrong dislike of the focus on the issue of selfdetermination, which Humphrey hints may stem in part from his French background. De Seynes' comments on the Greek proposal for a communications procedure reveal scorn for the idea of "obviously" sterile and endless debate on hu man rights violations. Humphrey's comments about de Seynes must be read with a more critical eye, however. While he paid constant respect to the brilliance and admitted a personalliking of the Secretary-General, very few words of praise are directed towards de Seynes. Nonetheless, when Humphrey was shocked by Bunche's attitude on self-determination, he felt that de Seynes had the most "penetrating and understanding mind" at the meeting. ${ }^{219}$

${ }_{217}$ Hobbins, supra note 24, at p. 175 (diary entry 17 September 1955).

m Urquhart, supra note 1, at p. 36 (personalfriends) and p. 82 (fine st negotiator).

${ }_{219}$ Hobbins, supra note 24, at p. 175. 
The attitude of Humphrey himself must also be considered. The Secretary-General once referred to him as "too zealous." 220 In 1953 there was some discussion of putting forth Humphrey's name as candidate for the Registrar of the International Court of Justice. Humphrey asked Judge John E. Read to withdraw his name as candidate: "I came to the conclusion that my duties as Registrar might be too passive for a person of my temperament ... [A]s Registrar, I would have relatively little opportunity to contribute towards the more dynamic aspects of your work." ${ }^{221}$ This view of his role as active and dynamic may well have made the Secretary-General uneasy about Humphrey's role in a neutral and bureaucratic Secretariat. This may have influenced the degree of latitude he wished to accord him. However there is no indication that another person would have been given more latitude. The real issue appears to be the degree to which the policies of the office of SecretaryGeneral were upheld in the Division. Where they were, more discretion would obviously be accorded, but only to implement what was expressly approved.

\section{Philosophical Considerations: Realism vs. Idealism}

Hammarskjöld was the quintessential diplomat. "[H]e combined sound hard realism with an extraordinary imagination", ${ }^{222}$ and was"... pragmatic and non-doctrinaire in choosing the means [of solving social problems]". ${ }^{223}$ Hammarskjöld felt Humphrey was over-zealous and that his "idealism" was an asset exactly where he was, in the Division of Human Rights. ${ }^{224}$ Urquhart has recently suggested that " ... it is possible that Hammarskjöld may have been made uneasy by the evangelical attitude of the Human Rights Division". ${ }^{225}$ Human rights approaches to international issues are inherently inflexible. They tend by their very nature to bestow entitlements that should not be compromised. In Hammarskjöld 's actions the objective was not to apportion blame. It was usually to reconcile two sides of a conflict, and bring them to an agreement, irrespective of which side bore the greater blame.

While there is some truth to this explanation, it is not a clear-cut matter. First, Hammarskjöld professed great respect for the rule of law, and its importance in international relations. In this respect he was fundamentally different from realists, who believe that power is the only factor worthy of analysis in international relations. ${ }^{226}$ Secondly, he had a morally and spiritually imbued view of his own role and that of the

${ }_{220}$ Humphrey, supra note 41, at p. 105, which Humphrey acknowledges as possibly true.

221 John P. Humphrey, Letter to Mr. Justice John E. Read, International Court of Justice, 8 May 1953. McGill University Archives, MG 4127, Cont. 23, File 472.

222 Cordier, supra note 13, at p. 16.

${ }_{223}$ Zacher, supra note 6, at p. 12.

${ }_{224}$ Hobbins, supra note 24. For full context see note 84.

${ }_{225}$ Letter from Sir Brian Urquhart to A. J. Hobbins (7 March 2(02) on file with A. J. Hobbins.

226 For a recent treatment by a renowned human rights scholar, see Jack Donelly, Realism in International Relations (Cambridge: Cambridge University Press, 2(01). 
UN. He was no mere pragmatist, but believed in moral duty. Third, his discourse towards the end of his tenure tended increasingly, if hypocritically, towards the importance of taking a stand on principle, as indicated in the introductions to his two final reports to the General Assembly.

Nor at the same time was Humphrey a politically naïve missionary out to save the world. He had a clear perception of the boundaries of his own office, though he admitted to overstepping them from time to time. He advocated taking the clause on self determination out of the Covenants on human rights for purely political reasons. He put forth the idea that Krishna Menon (India) be cast as the saviour of the Covenants in order to get him to lead the developing nations away from insistence on the inclusion of Art. 1. He was a proponent of quiet diplomacy throughout his own work, but in an effort to promote rather than suppress human rights. He appeared to remain on good terms with the American delegation, despite his criticisms of some of their policies. He also commented several times on the political constraints of his own office and the political realities of human rights at the time. He even went so far as to suggest that De Seynes and Hammarskjöld had been naïve in opposing the US resolution on technical assistance for human rights and the freedom of information. It is interesting to note that eventually they both backed down from their initial position, though de Seynes remained privately opposed.

Thus any difference in style or approach between the Secretary-General and the Division of Human Rights under Humphrey is difficult to sum up under simple terms. Both believed strongly in justice, but the roles each played were quite different. Their relationship is a difficult case study for a comparison of realism and idealism since each approach was premised on the particular role each had at the UN Had the roles been reversed, presumably the emphasis on approaches would have been changed. With regard to Hammarskjöld alone, it seems true that he felt justice was best served by a more pragmatic, ad hoc application of his powers than a uniform principled approach. Yet this was itself a manifestation of principle; that peace ought to be his chief concern. The real issue is not so much whether Hammarskjöld was willing to trump principle for national interests consistently, but whether he was correct in believing that human rights were inconsistent with his strategy. It would appear that he was not in bad faith about the role of principle and human rights at the UN, but that he was simply wrong about the potential negative effects of the hu man rights programme.

\section{Conclusions}

The conclusionsfrom this study may be put simply. Dag Hammarskjöld actively deflated the role of the human rights programme of the United Nations while he served as Secretary -General. Initially he was hostile, and later merely neglectful. The justifications of economy and controversy do not provide sufficient explanation for the particular actions. It seems likely that the Secretary-General's desire to run things his way, the influence of his aides, and his general background may explain his attitude. On the whole, one is left with the impression that the admittedly brilliant Secretary-General may and perhaps ought to have acted differently. The question of how remains to be addressed. 
It would be too simplistic to suggest that the Secretary-General should have been an open advocate of human rights at the time. His political role required the confidence of the Great Powers, without whose support the success of the organization as a medium for peace would wither. However different approaches were possible. First, the Secretary-General should not have imposed a unitary conception of the purpose of the UN While some administrative streamlining and unity of purpose are desirable, diversity should be left to flower, and be pruned only when detrimental to the stated purposes of the organization. Hammarskjöld's vision of a rationalized, efficient, and streamlined Secretariat may simply have been inconsistent with the realities of international bureaucracy, which must service numerous interests in various ways. While it is necessary for the Secretary-General to provide leadership and vision, such a vision should be wide and embracing of all activities emanating from the Secretariat and the Organs, not those with which his or her office is primarily occupied. This can be expressed by taking a balanced, active and publicly demonstrated interest in all the main substantive UN activities. Reading the last few of Hammarskjöld 's introductions to the Annual Reports, one is left wondering whether peace-keeping is the only function of the UN.

It is also important for the Secretary-General to emphasize the difference between his or her office and the Secretariat at large. While the Secretary-General is responsible for appointing staff under Art. 101, it is not imp lied that the staff is to serve his or her office alone. The opposite is indicated. It was in part the apparent need for unity that tied the DHR to the perceived diplomatic constraints of the Secretary-General's office. It would have been possible and beneficial to take a more removed approach to action within the Secretariat. The Secretary-General may have remained officially aloof on sensitive questions, while feigning any politically necessary disapproval to key delegations through quiet diplomacy. In this way, the Secretary-General could retain the personal confidence of the Great Powers. Meanwhile, the Director of the DHR (later Centre for Human Rights and now High Commission for Human Rights), could have played a more active role in quiet diplomatic advocacy of other, hopefully realistic objectives. This is a mere shadow of the open advocacy role of the current UN High Commissioner for Human Rights, which has been fruitful and without painful repercussions for the office of the Secretary-General. These goals could have been achieved by Hammarskjöld through simply cutting the Division less drastically, abstaining from expressing constant disapproval on human rights issues, and giving the Director more discretion and encouragement for creativity. This was the attitude he adopted towards the seminar programme, which led to positive results. A similar policy on other issues may have helped the UN human rights programme through its coldest era.

Finally the Secretary-General ought to have placed more reliance on the expertise of Secretariat staff, even when their abilities or judgment seemed inferior to his own or that of his senior aides. The Secretariat is not a tight circle of philosopher kings serviced by a few thousand clerks: it is rather an international civil service of representative character. Varying modes of expertise and experience contribute to it, and make it an institution over which the entire world may claim ownership. Whatever the predominantly administrative role the Secretariat of the UN is supposed to carry out, practice demonstrates that it has a significant influence on policymaking. Excellent leadership 
should leave Secretariat colleagues feeling as though each has contributed meaningful parts to a unified whole.

Now that the post of High Commissioner for Human Rights has been created, and a near formal division between Secretary-General and High Commissioner institutionalized, these observations may be regarded by some as moot.227 However, the relationship between Hammarskjöld and human rights is more than history alone. The High Commissioner enjoys the rank of Under Secretary-General, and is chosen by the Secretary-General with the approval of the General Assembly. While Kofi Annan is to be praised for choosing a strong and outspoken leader in Mary Robinson, it is possible that future Secretaries-General wil1 not wish to complicate the political role of their office. Thus it would be wise from this moment onwards to emphasize repeatedly the symbolic separation of the offices of Secretary-General and High Commissioner, until a strong tradition of independence exists for the latter. At this point, both offices will become insulated and fortified within the spheres of their most useful service.

227 Ironically, Humphrey had proposed and advocated the creation of UN High Commissioner for Human Rights for the very reason of separating the UN human rights mission from the Secretary-General. See AJ. Hobbins, "Humphrey and the High Commissioner: the Genesis of the Office of the UN High Commissioner for Human Rights", Journal of the History of International Law, Vol. 3 (200 I), p. 38. 